Journal of Marine Systems

October 2017, Volume 174, Pages 89-105

http://dx.doi.org/10.1016/i.jmarsys.2017.05.009

http://archimer.ifremer.fr/doc/00388/49903/

(C) 2017 Elsevier B.V. All rights reserved.

\title{
Impact of urban effluents on summer hypoxia in the highly turbid Gironde Estuary, applying a 3D model coupling hydrodynamics, sediment transport and biogeochemical processes
}

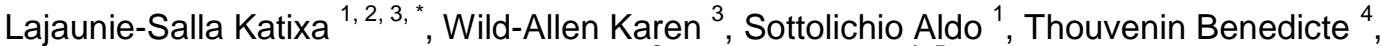 \\ Litrico Xavier ${ }^{2}$, Abril Gwenaël ${ }^{1,5}$
}

${ }^{1}$ Université de Bordeaux, Laboratoire EPOC, Environnements et Paléoenvironnements Océaniques et Continentaux UMR 5805, CNRS, Pessac, France

${ }^{2}$ LyRE, SUEZ Research Center, Bordeaux, France

${ }^{3}$ CSIRO Marine and Atmospheric Research, Hobart, Tasmania, Australia

${ }^{4}$ IFREMER, Plouzané, France

${ }^{5}$ Departamento de Geoquímica, Universidade Federal Fluminense, Niterói, RJ, Brazil

* Corresponding author : Katixa Lajaunie-Salla, email address : k.lajauniesalla@epoc.u-bordeaux1.fr

\begin{abstract}
:
Estuaries are increasingly degraded due to coastal urban development and are prone to hypoxia problems. The macro-tidal Gironde Estuary is characterized by a highly concentrated turbidity maximum zone (TMZ). Field observations show that hypoxia occurs in summer in the TMZ at low river flow and a few days after the spring tide peak. In situ data highlight lower dissolved oxygen (DO) concentrations around the city of Bordeaux, located in the upper estuary. Interactions between multiple factors limit the understanding of the processes controlling the dynamics of hypoxia.
\end{abstract}

A 3D biogeochemical model was developed, coupled with hydrodynamics and a sediment transport model, to assess the contribution of the TMZ and the impact of urban effluents through wastewater treatment plants (WWTPs) and sewage overflows (SOs) on hypoxia. Our model describes the transport of solutes and suspended material and the biogeochemical mechanisms impacting oxygen: primary production, degradation of all organic matter (i.e. including phytoplankton respiration, degradation of river and urban watershed matter), nitrification, and gas exchange. The composition and the degradation rates of each variable were characterized by in situ measurements and experimental data from the study area. The DO model was validated against observations in Bordeaux City.

The simulated DO concentrations show good agreement with field observations and satisfactorily reproduce the seasonal and neap-spring time scale variations around the city of Bordeaux. Simulations show a spatial and temporal correlation between the formation of summer hypoxia and the location of the TMZ, with minimum DO centered in the vicinity of Bordeaux. To understand the contribution of the urban watershed forcing, different simulations with the presence or absence of urban effluents were compared. Our results show that in summer, a reduction of POC from SO would increase the DO 
minimum in the vicinity of Bordeaux by $3 \%$ of saturation. Omitting discharge from SO and WWTPs, DO would improve by $10 \%$ of saturation and mitigate hypoxic events.

\section{Highlights}

- A biogeochemical model coupled with a 3D hydrodynamics and sediment transport model was implemented in the Gironde Estuary, accounting for realistic watershed and urban inputs of POC. The simulated DO concentrations showed good agreement with field observations and satisfactorily reproduced the seasonal and neap-spring time scale variations around the city of Bordeaux, including summer hypoxia in the upper estuary $\rightarrow$ A reduction of POC from sewage overflows would increase the DO minimum in the vicinity of Bordeaux by $3 \%$ of saturation, and omitting all wastewater discharge DO would improve by $10 \%$ of saturation and mitigate hypoxic events.

\section{Abbreviations}

- DO, dissolved oxygen;

- DOC, dissolved organic carbon;

- DOM, dissolved organic matter;

- NT, neap tide;

- POC, particulate organic carbon;

- POM, particulate organic matter;

- SSC, suspended sediment concentration;

- SO, sewage overflow;

- ST, spring tide;

- $\quad T M Z$, turbidity maximum zone;

- TOC, total organic carbon;

- WS, watershed;

- WWTP, wastewater treatment plant

Keywords : Hypoxia, TMZ, Gironde Estuary, Wastewater, Oxygen, Modeling 


\section{Introduction}

Hypoxic areas are increasing globally and are a major environmental problem in shallow water estuaries (Diaz et Rosenberg, 2008; Diaz, 2001). Hypoxic waters are defined as areas where the concentration of dissolved oxygen (DO) is less than $2 \mathrm{mg} \mathrm{L}^{-1}(\sim 20-30 \%$ of air saturation or $62.5 \mu \mathrm{mol} \mathrm{L}^{-1}$, e.g., Rabalais et al., 2010). DO is an indicator of water quality in estuaries as it is essential for the health of aquatic ecosystems. Indeed, hypoxic zones cause ecosystem problems for benthic and pelagic fauna (Diaz, 2001; Gray et al., 2002).

Hypoxia is often a consequence of an increase in eutrophic areas induced by high concentrations of nutrients and organic substances delivered by rivers and human activities (Rabalais et al., 2010; Verity et al., 2006). This supply of material perturbs the biogeochemical cycle in aquatic systems. When oxygen consumption by community respiration is greater than the replenishment of DO by the atmosphere, vertical mixing or photosynthesis, DO depletion occurs (Conley et al., 2009). In temperate eutrophic estuaries, the input of nutrients and organic material intensifies primary production in spring and summer, producing organic matter in surface waters. Moreover, anthropogenic nutrient and organic matter enrichment intensifies hypoxic events by the rapid decay of labile organic matter during warmer months. In stratified estuaries, the settling of particulate organic matter and associated heterotrophic processes cause summertime DO depletion in bottom waters, as in Chesapeake Bay (Hagy et al., 2004) and the plume of the Yangtze River (Li et al., 2002). In contrast, in well-mixed estuaries (as Scheldt Estuary, Soetaert et al. (2006) or Ems Estuary, Talke et al. (2009)), hypoxia is less likely to occur due to wind and tide mixing driving DO replenishment from the atmosphere. In turbid estuaries, photosynthesis is low and DO 
depletion can be caused by the degradation of organic matter, which is associated with the suspended sediment (Lanoux et al., 2013; Talke et al., 2009; Thouvenin et al., 1994).

Hypoxic events occur in the well-mixed and macro-tidal Gironde Estuary, associated with the presence of a turbidity maximum zone (TMZ) resulting from the asymmetry of the tidal wave in the upper estuary coupled to the density residual circulation (Allen et al., 1980; Brenon and Le Hir, 1999). The Gironde Estuary is a heterotrophic ecosystem (Abril et al., 2002, 1999; Etcheber et al., 2007; Irigoien and Castel, 1997) with oxygen concentrations relatively close to saturation in the river water and at the mouth of the estuary and between 20 and $70 \%$ saturation in the TMZ (Abril et al., 1999). Phytoplankton grows mainly in the river and at the mouth of the estuary, and the heterotrophic bacterial population grows preferentially in the TMZ (Goosen et al., 1999). The turbidity limits primary production due to light attenuation in the water column and favors DO consumption by heterotrophic processes (Goosen et al., 1999). In addition, turbidity limits gas exchange in the TMZ (Abril et al., 2009). DO depletion occurs in the water column of the TMZs of many European macro-tidal estuaries (Amann et al., 2012; Garnier et al., 2001; Lanoux et al., 2013; Soetaert et al., 2006; Talke et al., 2009; Thouvenin et al., 1994; Tinsley, 1998; Villate et al., 2013). These high turbidity zones play a key role in the sedimentation and biogeochemical processes that control the environmental water quality (Abril et al., 2000, 1999).

A analysis of 7 years of DO data from the water quality monitoring in the Gironde Estuary (Etcheber et al., 2011) showed that summer hypoxic events occurred in the TMZ coincident with lower river discharge and higher water temperature. Moreover, DO minima occurred a few days after the spring tide (ST) peak, with lower concentrations near the city of Bordeaux in the upper reaches of the estuary (Lanoux et al., 2013). Various factors explain the hypoxic events in the Gironde Estuary, including temperature, river flow, turbidity and urban effluents, however the relative contribution of each factor is not yet well known. In the future, 
increases in turbidity, water temperature and urban discharge, together with decreased flushing due to lower river flow, could lead to severe summer hypoxia. Numerical modeling can help coastal policymakers make informed decisions for managing the Gironde estuary by determining to what extent reducing organic matter and nutrient inputs, or altering wastewater treatment, may impact hypoxia (Kemp et al., 2009). For example, in the Thames and Scheldt Estuaries, the installation of wastewater treatment plants (WWTPs) notably increased oxygen concentrations and eliminated hypoxic zones (Amann et al., 2012; Soetaert et al., 2006; Tinsley, 1998). Biogeochemical models are essential tools for understanding ecosystem function, they enable the identification of diverse factors that control the dynamics of hypoxia (Lopes and Silva, 2006; Scully, 2013; Talke et al., 2009). Moreover, biogeochemical models can be used as a tool for effective estuarine management by providing guidelines for goal setting to improve water quality (Cox et al., 2009; Justić et al., 2007; Skerratt et al., 2013; Vanderborght et al., 2007; Wild-Allen et al., 2009).

The aims of this paper are 1) to build a model fit for the assessment of estuarine oxygen dynamics; 2) to assess the impact of TMZs in the Gironde Estuary on the size and position of the hypoxic area; and 3) to quantify the contribution of organic matter from the river watershed (WS) and organic matter and ammonia from the local urban watershed (WWTP and sewage overflow (SO)) to estuarine hypoxia. Previous works have demonstrated that the TMZ in the Gironde Estuary is characterized by strong vertical suspended sediment concentration (SSC) gradients, which are maintained by salt-induced density stratification, especially in the lower estuary under high river flow (Sottolichio et al., 2000). As these vertical gradients and the resulting horizontal sediment fluxes cannot be reproduced using a depth-averaged model, we implemented a 3D biogeochemical model coupled with both a hydrodynamics and a suspended sediment transport model to reproduce the DO dynamics in the Gironde Estuary 


\section{Materials and methods}

\section{$2.1 \quad$ Study area}

The Gironde Estuary is located in Southwest France on the Atlantic Coast, near the city of Bordeaux. It is formed by the confluence of the Garonne River, which provides $65 \%$ of the freshwater input and the Dordogne River, which provides $35 \%$ of the freshwater input and drains a watershed of $81000 \mathrm{~km}^{2}$ (Figure 1). The Gironde Estuary is the largest European estuary, with a surface area of $635 \mathrm{~km}^{2}$. Transect distances along the estuary are noted by kilometric points $(\mathrm{PK})$, where the origin (PK0) is in Bordeaux (the monitoring station is located at PK4), PK100 is at the mouth and PK-70 is the upstream limit of tide propagation. The Gironde Estuary is shallow, with a depth range from 5 to $8 \mathrm{~m}$ and a depth of up to $20 \mathrm{~m}$ near the mouth (Sottolichio and Castaing, 1999). The annual mean river flow is $680 \mathrm{~m}^{3} \mathrm{~s}^{-1}$ (sum of Garonne and Dordogne Rivers) as calculated over the recent period 2005-2014 by Jalón-Rojas et al. (2015) and the estuary is classified as partially to well-mixed macro-tidal (Allen, 1972). The tidal amplitude at the mouth varies from $2.5 \mathrm{~m}$ at neap tides (NT) to $5 \mathrm{~m}$ at spring tides (ST, Allen et al., 1980). The tidal wave propagates up to $170 \mathrm{~km}$ from the estuary mouth to La Réole on the Garonne River (PK-70, $95 \mathrm{~km}$ from the river confluence) and to Pessac-sur-Dordogne on the Dordogne River (90 km from the river confluence). The residence time of water in the estuary ranges from 20 to 86 days, depending on the fluvial regime (Jouanneau and Latouche, 1981).

In the TMZ, the suspended sediment concentration (SSC) in the surface waters varies between 0.1 and $10 \mathrm{~g} \mathrm{~L}^{-1}$ and the residence time of suspended particles is estimated to be between 12 and 24 months (Saari et al., 2010). The TMZ migrates longitudinally during the semi-diurnal tidal cycle (modulated by the spring-neap cycle) and throughout the year, modulated by river flow variation and horizontal excursion of the salinity intrusion. In winter, 
under high river flow, the TMZ is located downstream Pauillac City, approximately at the PK45 (Doxaran et al., 2009). When the river flow decreases, the TMZ moves upstream, oscillating from the junction of the two rivers (Bec d'Ambes) to Portets on the Garonne River and to Libourne on the Dordogne River, i.e., PK-20 (Castaing and Allen, 1981) (Figure 1). The vertical distribution of the SSC is controlled by the tidal currents. At slack water, mostly at neap tides, suspended matter settling occurs and an anoxic fluid mud appears at the bottom, forming elongated patches with concentrations greater than $100 \mathrm{~g} \mathrm{~L}^{-1}$ (Abril et al., 1999). The particulate organic carbon (POC) content in the $\mathrm{TMZ}$ is relatively constant at $1.5 \%$, with the major constituent being refractory soil material (90\%) with smaller contributions of biodegradable litter and autochthonous phytoplanktonic material (Etcheber et al., 2007).

The sewage system of Bordeaux City, located on the Garonne River (Figure 1), drains an urban area of $578 \mathrm{~km}^{2}$ and served an estimated population of 749,595 in 2015 . There are two large wastewater treatment plants that discharge treated water comprised mainly of ammonia, and 9 sewage overflows that discharge untreated water mainly consisting of POC (Figure 1) (Lanoux, 2013).

To understand the dynamics of the TMZ and the variation in DO, continuous water quality monitoring systems were installed at Pauillac, Portets and Libourne in 2004 and at Bordeaux in 2005 (Figure 1). These stations contain real-time systems (updated every 10 minutes) that measure 4 parameters: temperature, salinity, turbidity and DO, and continue to collect data to the present time (Schmidt et al., 2016). The values recorded between January 2005 and October 2006 (http://www.magest.u-bordeaux1.fr) were used in the current study to validate the numerical model (section 2.5). 


\subsection{Hydrodynamics and transport model for salt and fine sediment}

The SiAM-3D (Simulation for Multivariable Advection) model was initially developed to simulate the dynamics of estuarine suspended sediment and associated biogeochemical variables. A detailed description of the sediment transport model and its first application can be found in Brenon and Le Hir (1999) for the Seine Estuary and in Cugier and Le Hir (2002) for the Bay of Seine. This hydrodynamic and transport model was implemented in the Gironde Estuary by Sottolichio et al. (2000), and applied by Benaouda (2008), and Van Maanen and Sottolichio (2013). The hydrodynamic model solves the Navier-Stokes set of equations (momentum, continuity and state equations) under the Boussinesq approximation and the hydrostatic assumption in the vertical direction.

External and internal modes are separated to solve the set of equations. The external mode determines the free surface elevation and depth-integrated velocity ( $\mathrm{U}$ and V) from the 2D StVenant equation. Then, the free surface elevation is introduced into the internal modes to determine the three velocity components $(\mathrm{u}, \mathrm{v}, \mathrm{w})$. The turbulence model uses the eddy viscosity concept based on mixing length theory. The damping of turbulence by density stratification is taken into account by empirical functions using a Richardson number.

The transport model solves the advection/dispersion equations for the dissolved and particulate variables, i.e., salinity, suspended sediment and biogeochemical variables. The equation for suspended sediment accounts for the main cohesive sediment processes: erosion, deposition, flocculation, consolidation and hindered settling (Appendix Table A1). The deposition flux is calculated using the Krone (1962) formulation, and the erosion flux, by the Partheniades (1965) formulation (Appendix Table A1). 


\subsection{Biogeochemical model}

The biogeochemical model is based on the $1 \mathrm{D}$ model previously developed by Thouvenin et al. (1994) for the Loire Estuary. In in this study the biogeochemical model developed was fully coupled to the three-dimensional SiAM-3D hydrodynamic and sediment transport model. The model simulates biogeochemical processes that produce or consume oxygen in the water column taking into account different types of dissolved and particulate organic matter. These biogeochemical processes include the degradation of organic matter (mineralization of organic carbon and ammonification using the $\mathrm{C} / \mathrm{N}$ ratio), nitrification, photosynthesis, respiration and mortality of phytoplankton, and DO gas exchange with the atmosphere (Figure 2). For each layer and grid cell, the time evolution of each model variable $(\mathbf{C})$ is the sum of conservative advection and diffusion processes $(\varphi \mathbf{C})$ and biogeochemical rate processes $\left(\beta_{C}\right.$, Appendix Table A2):

$\frac{\partial \boldsymbol{C}}{\partial t}=-\varphi \boldsymbol{C}+\beta_{\boldsymbol{C}}+S_{\boldsymbol{C}}$, with $\varphi \boldsymbol{C}=\frac{\partial\left(u_{i} \boldsymbol{C}\right)}{\partial x_{i}}-\frac{\partial\left(K_{i} \frac{\partial \boldsymbol{C}}{\partial x_{i}}\right)}{\partial x_{i}}$

where $\mathbf{C}$ is the variable concentration, $S_{\boldsymbol{C}}$ the external input, $K_{i}$ is the turbulent diffusivity coefficient, and $u_{i}$ is the current in the $x_{i}$ direction with $i=x, y$ or $z$.

The model includes 11 state variables (Figure 2): dissolved oxygen (DO), ammonia $\left(\mathrm{NH}_{4}{ }^{+}\right.$), nitrate $\left(\mathrm{NO}_{3}^{-}\right)$and particulate and dissolved organic carbon (POC and DOC) from the watershed and wastewater. Watershed sources include POC from litter $\left(\mathrm{POC}_{\text {litter }}\right)$, which is the biodegradable fraction of terrestrial POC eroded from the Garonne and Dordogne watersheds (Etcheber et al., 2007; Veyssy, 1998), and DOC from rivers (DOC fluvial) (Veyssy, 1998). For wastewater, the model includes the POC and DOC from wastewater treatment plants $\left(\mathrm{POC}_{\mathrm{WWTP}}\right.$ and $\left.\mathrm{DOC}_{\mathrm{WWTP}}\right)$ and from sewage overflows $\left(\mathrm{POC}_{\mathrm{SO}}\right.$ and $\left.\mathrm{DOC}_{\mathrm{SO}}\right)(\mathrm{Lanoux}$, 
2013). The model also considers POC from phytoplankton ( $\left.\mathrm{POC}_{\text {phytoplankton}}\right)$ and detritus (POC detritus$_{\text {) }}$ (Etcheber et al., 2007; Lemaire, 2002; Lemaire et al., 2002). Dissolved variables are advected and diffused similar to salinity whilst particulate variables settle and can be resuspended similar to suspended sediment. POC has the same settling velocity as light particles, except for $\mathrm{POC}_{\text {litter }}$ which has the same settling velocity as the heavy particles (Appendix Table A1).

Modifications from the previous version of the biogeochemical model were introduced to include photosynthesis and nitrification processes and to differentiate the degradation rates of organic matter from rivers and urban watersheds. The organic carbon mineralization rates are derived from experimental data obtained using material from the Garonne watershed (litter, $k_{P}^{\text {litter }}$; fluvial, $\left.k_{D}^{\text {fluvial }}\right)$, phytoplankton $\left(k_{R}\right.$ and $\left.k_{P}^{\text {detritus }}\right)$ (Etcheber et al., 2007; Lemaire, $2002)$ and the Bordeaux sewage network for WWTP $\left(k_{P}^{W W T P}\right.$ and $\left.k_{D}^{W W T P}\right)$ and SO $\left(k_{P}^{S O}\right.$ and $k_{D}^{S O}$ ) (Lanoux, 2013). These organic carbon mineralization rates account for the high lability of material from urban effluent and for the more refractory character of organic carbon from the watershed (Lanoux, 2013; Lemaire et al., 2002; Appendix Table A4). Boundary conditions for each biogeochemical variable were derived from in situ data obtained in previous years from the Garonne and Dordogne Rivers, the Gironde Estuary, and the sewage network of the city of Bordeaux (Table 1). Simulated phytoplankton primary production is limited by temperature $(f(T))$, nutrient availability $(f(N))$ and light attenuation $(f(I))$ in the water column due to turbidity (Irigoien and Castel, 1997), and we account for preferential uptake of ammonia vs nitrate $\left(\alpha_{N}\right)$ (Appendix Table A3). The molar $\mathrm{C} / \mathrm{N}$ (Appendix Table A4) ratio of organic matter, which controls the relative rates of organic carbon mineralization and ammonification, is set to 10 for litter and wastewater (Middelburg and Herman, 2007) and to the Redfield value of 6 for phytoplankton. Nitrification of $\mathrm{NH}_{4}{ }^{+}$consumes 2 moles of DO, giving 1 mole of $\mathrm{NO}_{3}{ }^{-}$(Appendix Table A4). The formulation of the gas exchange rate 
( $k_{\text {aera }}$, Appendix Table A3) is derived from floating chamber measurement of the $\mathrm{CO}_{2}$ flux in the Gironde Estuary (Abril et al., 2009) and takes into account the magnitude of the current velocity, wind, the surface area of the estuary (fetch effect) and SSC (attenuation of turbulence).

Based on previous field and experimental research (Abril et al., 2010, 2000, 1999) highlighting slow anaerobic carbon remineralization rates in the fluid mud, seabed oxygen consumption was simulated using a simple constant benthic oxygen demand. Denitrification and $\mathrm{Mn}$ reduction are the major respiratory pathways in the fluid mud, forming $\mathrm{NH}_{4}{ }^{+}$and $\mathrm{Mn}(\mathrm{II})$ in low concentrations. Owing to the modest volume of the estuary occupied by the fluid mud pools (maximum of $10 \%$ of the water column in the TMZ at neap tides), the oxidation of inorganic reduced species during resuspension events has a negligible effect on water column oxygenation, even at spring tide (Abril et al. 1999). Thus, we simplified the fluid mud biogeochemistry and applied a POC degradation rate 10 times slower than in the water column. However, the supply of particulate organic matter by fluid mud resuspension has a major effect on the water column oxygenation in the model by increasing the SSC by a factor of 5 to 10 at spring tides compared to neap tides. Finally, we did not implement denitrification in the biogeochemical model because denitrification does not interact directly with dissolved oxygen. In previous fieldwork studies (Abril et al., 2000) showed, that even if denitrification occurs in the fluid mud, it likely has a modest impact at the estuarine scale, as nitrate concentration is first increased by nitrification in the low salinity region of the TMZ and then behaves relatively conservatively along the Gironde Estuary salinity gradient.

A summary of the biogeochemical model equations and parameters values is included in Appendix table A2, A3 and A4. 


\subsection{Model implementation}

The computational domain, defined in Sottolichio et al. (2000) extends from the $200 \mathrm{~m}$ isobath on the continental shelf to the upstream limits of the tidal propagation on both rivers (Figure 1). The model is implemented for the Gironde Estuary on an irregular rectilinear grid (2421 wet cells in the horizontal), with finer resolution in the estuary $(200 \mathrm{~m} \mathrm{x} 1 \mathrm{~km}$ ) and coarser resolution on the shelf. The vertical grid uses real depth coordinates. The vertical axis is split into 12 layers bounded by fixed horizontal levels, with progressively finer resolution from the bottom to the free surface. In the area of interest in the Garonne tidal river around Bordeaux, the water column layers are $2 \mathrm{~m}$ thick, which is satisfactory for estuarine sections (see Cugier and Le Hir, 2002 for more detail). The tidal rivers are represented by one cell in width but are discretized vertically and longitudinally. The spatial resolution in the longitudinal direction is $1 \mathrm{~km}$ on the Garonne River and between 1 and $4 \mathrm{~km}$ on the Dordogne River, with finer resolution in the upper reaches. The model uses a finite difference numerical scheme, with a transport time step of $35 \mathrm{~s}$ and simulations run with a run-time to real-time ratio of $\sim 184: 1$. The model is forced with tidal elevation at the shelf, which is provided by harmonic composition. At the upstream limit of the Garonne and Dordogne Rivers, a daily river flow is imposed (data available from HydroBank, www.hydro.eaufrance.fr). The model is initialized using a total fine sediment budget of 3.84 million tons and a horizontal salinity gradient (Van Maanen and Sottolichio, 2013). The hydro-sedimentary model was previously validated in the lower estuary and was found to perform well against observations of tide, currents, salinity and SSC (Benaouda, 2008; Sottolichio et al., 2000; Van Maanen and Sottolichio, 2013). Forcing of the seasonal water temperature (water quality monitoring, http://www.magest.u-bordeaux1.fr), wind and incident light intensity (Météo France) are included for accurate simulation of the DO dynamics. 
For the biogeochemical model, the nutrient, organic carbon and phytoplankton concentrations at the boundaries are derived from Veyssy (1998) and Abril (unpublished data), and the oxygen concentrations at the boundaries are set to $90 \%$ sat in the Garonne and Dordogne Rivers and at $100 \%$ sat in the sea water (Abril et al., 1999) (Table 1). Urban wastewater discharge points are included in the model: 9 SOs and 2 WWTPs (Figure 1). The concentrations of POC, DOC and ammonia from the urban effluents are from Lanoux (2013) (Table 1), and the discharge volume is from the wastewater management company SUEZ, which operates the wastewater network for the Bordeaux metropolis.

\subsection{Model validation}

The purpose of the model built in this study was to understand the DO dynamics of the Garonne River at Bordeaux, particularly during summer conditions, to support management decisions. Following the recommendations of Rykiel (1996), to validate the performance of our model sufficient for our scientific purposes, three criteria were selected:

1. The model reproduces the timing of the observed DO fluctuations at seasonal and neapspring time scales, in the vicinity of Bordeaux City.

2. The model reproduces the observed DO amplitude in the vicinity of Bordeaux City.

3. The model vs observed Willmott Skill Score (WSS) is greater than 0.7 for water level, salinity, SSC and DO in the vicinity of Bordeaux City.

For the statistical validation (3), we calculated the bias and WSS (Willmott, 1982) at the two water quality monitoring network stations located on the Garonne River (Bordeaux and Portets) for the years 2005 and 2006 (Figure 3 and Table 3). Model results at Bordeaux were compared with observational data from the continuous MAGEST network over the whole simulation period (from $1^{\text {st }}$ of January to the $30^{\text {th }}$ of October 2006, Figure 4) and for the 
month of September 2006 to illustrate detailed patterns at tidal frequencies (Figure 5). This period was used because 2006 was a dry year, a significant hypoxic event occurred in summer, and continuous monitoring data were of high quality for this year with few gaps.

As stated in section 2.2, the sediment transport model was previously validated in the lower estuary only, i.e., downstream of the confluence of the Garonne and Dordogne Rivers. In this study the fluvial portion of the estuary (Garonne tidal river) was simulated for the first time. Validation of the simulated tide and SSC was therefore performed simultaneously with the validation of the biogeochemical model. The previous hydrodynamic calibration (based on the adjustment of bottom friction) was maintained to simulate the tides and currents, but a new paramaterization was applied for suspended sediments. In particular, we included a dependence of settling velocity $\mathrm{w}_{\mathrm{s}}$ on salinity to account for deflocculation processes in brackish and freshwater (Appendix, Table A1). This effect was negligible in the salty lower estuary, but had a significant effect on the stability of flocs when they were transported into the tidal river. Settling velocity, $\mathrm{w}_{\mathrm{s}}$ varied between 0.1 and $2 \mathrm{~mm} \mathrm{~s}^{-1}$ in the lower estuary and can decreased to $0.02 \mathrm{~mm} \mathrm{~s}^{-1}$ in the area with salinity $<5 \mathrm{psu}$. These values were optimized to simulate relatively high SSC and maintain the TMZ within the river by limiting seaward SSC dispersion.

We validated the transport model with turbidity data, from a station near the bank. As the model calculates the width-averaged SSC, some discrepancies between the model and measurements were expected. At the start of the reference simulation in winter conditions, the river flow was high (Figure $4 \mathrm{~b}$ ) and the TMZ was located in the lower estuary (Figure 6a), so surface SSC was minimal in Bordeaux (Figure 4d). After flood peaks in February, March and April, the river flow progressively decreased to a minimum value at the end of August (Figure 4b). The SSC at Bordeaux started to increase between May and June and 
reached its maximum value between July and September, when the TMZ moved into the upper estuary (Figure 6b). In summer, the simulated SSC was lower than observed, even when using the optimized settling velocity. The observation site was located in shallow water near a tidal flat with locally high SSC; by contrast, the model grid cell integrates the whole channel, where SSC can be 2-3 times lower than nearshore. In addition, turbidity was measured in NTU and converted to $\mathrm{g} \mathrm{L}^{-1}$ using an empirical calibration. A simple conversion was used $\left(10000 \mathrm{NTU}=6 \mathrm{~g} \mathrm{~L}^{-1}\right)$ based on the laboratory calibration reported by Jalón-Rojas et al. (2015), which may have overestimated the SSC. Despite these discrepancies, the observed dynamic and relative variability in SSC are accurately reproduced by the model at the seasonal scale (Figure 4d) and at the fortnightly tidal scale (Figure 5d), with an increase in SSC during the spring tide.

In Bordeaux City, the hydrodynamic was well simulated; the model skill (WSS) for the water level and salinity was greater than 0.7 (Table 3 ). For SSC, the model skill was lower $(0.53)$ for the reasons explained above. Tidal records were not available further upstream, so at Portets, the evaluation of the model skill was limited to salinity and SSC and the model skill was less than 0.5 . This was partly due to low variability in salinity in the upper estuary (salinity $<1$ ), and the simulated late arrival of the TMZ in the upper Garonne River which limited the upstream propagation of DO impact to Portets.

For the biogeochemical model, the main parameters used in the reaction equations were derived directly from experimental data (see Table A3); there were no specific adjustments or calibration of these parameters in the model. The observed seasonal and neap-spring time scale DO dynamics were well simulated near Bordeaux City (Figure 4c and 5c) and the model skill at this station had a satisfactory WSS value of 0.77 (Figure 3 and Table 3 ). At the seasonal scale, the model reproduced the progressive DO reduction in summer, which was 
caused by the increase in temperature and SSC at the end of May (Figure 4). The model also accurately reproduced the observed DO amplitude (between 20\%sat and 120\%sat), with model variation between $30 \%$ sat and $100 \%$ sat. The observed DO maximum at $120 \%$ sat in May was due to a spring bloom of phytoplankton that was not well simulated by the model. In general the timing of simulated DO depletion occurred a few days later than observed, which can be explained by the movement of the TMZ upstream to Bordeaux $\sim 20$ days later than observed (Figure 4). Nevertheless, starting in July, there was good agreement between the model and the in situ data, with a DO bias of $10 \%$ sat. DO was modulated by the semidiurnal tide (Figure 5c). As described by Lanoux et al. (2013), during the spring-to-neap tide transition (from 09/10 to 09/15), when the turbidity was high, a decrease in DO occurred. Later, an increase in DO was recorded between 09/15 and 09/20, which corresponded to a peak in the river flow. The model accurately reproduced the observed variability at all significant time scales, with no specific calibration of biogeochemical parameters. The mechanisms involved in these dynamics will be explored in greater detail in section 3.2.

In summary, the simulated hydrodynamics in the Garonne tidal river near Bordeaux were in good agreement with observations. We simulated the seasonal movement of the TMZ from the lower estuary into the Garonne River at low river flow in summer, as described in the previous work of Jalón-Rojas et al. (2015) and Sottolichio and Castaing, (1999). The modelled DO variation was also well simulated in the vicinity of Bordeaux. We conclude that the model has sufficient skill to provide robust simulation and explanation of the seasonal and tidal dynamics of oxygen in the vicinity of Bordeaux, however, model results in the upper reaches of the Garonne River should be considered with more caution. 


\subsection{Sensitivity analysis}

We identified the key processes affecting oxygen in the vicinity of Bordeaux and then selected which parameters of these processes to perturb. The largest rates contributing to DO variation in the water column were in order of increasing importance: the degradation of TOC (total organic carbon, $\mathrm{POC}+\mathrm{DOC})$ from the watershed $\left(\mathrm{POC}_{\text {litter }}\right.$ and $\left.\mathrm{DOC}_{\text {fluvial }}\right)$, of $\mathrm{POC}$ from WWTP, of POC from SO, nitrification and aeration.

The parameters selected for assessment were: (1) kinetics of degradation of POC from SO, $\mathrm{k}_{\mathrm{P}}^{\mathrm{SO}}$; (2) kinetics of degradation from WWTP, $\mathrm{k}_{\mathrm{P}}^{\mathrm{WWTP}}$; (3) kinetics of degradation from litter, $\mathrm{k}_{\mathrm{P}}^{\text {litter }}$; (4) kinetics of degradation from fluvial, $\mathrm{k}_{\mathrm{D}}^{\text {fluvial}}$; (5) kinetics of nitrification, $\mathrm{k}_{\mathrm{nit}}(6)$ wind velocity, $\mathrm{U}_{10}$; and (7) river DO boundary conditions.

The sensitivity of modelled DO to parameter variation was calculated as:

Sensitivity $=\frac{V((1+a) p)-V((1-a) p)}{2 a V(p)},($ Carmichael et al., 1995)

where $\mathbf{V}(\mathbf{p})$ is the average or minimum DO in Bordeaux in 2006, $\mathbf{p}$ is the parameter value and $\mathbf{a}$ is the perturbation. The perturbation values are given in Table 2. If the sensitivity is close to 2, $\mathbf{V}$ is proportional to $\mathbf{p}^{2}$. A negative sensitivity value indicates a decrease in DO as the parameter increases.

According to Hadley et al. (2015), an absolute sensitivity value of 0.3 is the threshold for the model to be considered sensitive to that parameter. The DO mean is relatively insensitive to parameter variation for most of the selected processes $(\mathrm{S} 1<0.1$; Table 2$)$. However, the oxygen minimum is sensitive to $k_{P}^{\text {litter }}$ and wind velocity $(\mathrm{S} 2>0.60$; Table 2). DO in Bordeaux is also sensitive to the variation in the DO concentrations at the river boundaries ( $\mathrm{S} 1$ and $\mathrm{S} 2>0.6$; Table 2). For example, a reduction in the DO concentration from $90 \%$ sat to $80 \%$ sat in the river waters results in a reduction in DO of $6 \%$ sat in the Garonne River at 
Bordeaux. It is therefore important to constrain good quality data for the DO concentrations at the river boundaries to accurately determine the DO concentration at Bordeaux.

\section{Results}

\subsection{DO dynamics over seasonal time scale}

The model was reliable in simulating the seasonal patterns of SSC and DO, similarly to previous observations reported in the estuary. Horizontal simulated distributions of SSC and DO were plotted for two contrasted months (Figure 6). In winter, the TMZ was positioned in the lower estuary, with its center located downstream of Pauillac (Figure 6a). In the tidal rivers the bottom water SSC was less than $1 \mathrm{~g} \mathrm{~L}^{-1}$; the stock of sediment was dispersed downstream of the confluence of the Garonne and Dordogne Rivers and SSC was greater than $2 \mathrm{~g} \mathrm{~L}^{-1}$ over an area from Bec d'Ambès to the Talmont close to the mouth (Figure 6a) . At the same time, DO in surface waters was greater than $70 \%$ sat along the whole estuary (Figure 6c). In summer, at low river flow, the TMZ moved upstream into the rivers and in the Garonne River bottom SSC was higher $\left(>1.7 \mathrm{~g} \mathrm{~L}^{-1}\right.$ ) over the region up to Portets (Figure $6 \mathrm{~b}$ ). In the estuary, bottom SSC remained high between Pauillac and Bec d'Ambès (Figure 6b). In the Garonne River a drop in DO occurred, with surface DO concentrations lower than $60 \%$ sat for the month of July (Figure 6d). Although SSC and DO are not totally well correlated, the lowest DO area (with concentrations less than 40\%sat) was located around and downstream of Bordeaux City, close to the center of the TMZ (Figure 6d).

The spatial dynamics of surface SSC and DO were reflected in the temporal dynamics in the vicinity of Bordeaux (Figure 4c and 4d): the SSC in surface water was approximately 0.1-0.2 $\mathrm{g} \mathrm{L}^{-1}$ and DO was $90 \%$ sat in winter. At the beginning of June (summer), the river flow decreased to less than $150 \mathrm{~m}^{3} \mathrm{~s}^{-1}$ and reached a minimum value of $54 \mathrm{~m}^{3} \mathrm{~s}^{-1}$ and $52 \mathrm{~m}^{3} \mathrm{~s}^{-1}$ in 
August for the Garonne and Dordogne Rivers, respectively (Figure 4b). As a consequence, DO decreases concurrently with the arrival of the TMZ at Bordeaux, with a minimum of $29 \%$ sat (or $71 \mu \mathrm{mol} \mathrm{L}{ }^{-1}$ ) (Figure $4 \mathrm{c}$ and $4 \mathrm{~d}$ ).

Figure 7 shows the simulated evolution of the vertical structure of DO, SSC and salinity at the Bordeaux station in 2006. The distribution of oxygen throughout the water column was virtually homogenous, suggesting intense vertical mixing in the upper Gironde Estuary (Figure $7 \mathrm{~b}$, which was confirmed by the vertically homogenous distribution of salinity Figure 7d). A vertical SSC gradient occurred in the presence of the TMZ (Figure 7c), which was more noticeable under spring tides, when resuspension induced the maximum SSC near the bottom. The salinity (Figure 7d) was less than 2 psu, which suggested that Bordeaux was near the upper limit of salt intrusion.

The daily average rates of biogeochemical processes impacting DO (mineralization, nitrification, gas exchange) and TOC concentrations were calculated over the area of $6.6 \mathrm{~km}^{2}$, including the WWTP and the SO sites of Bordeaux (Figure 1, orange area in lower panel) (Figure $4 \mathrm{e}$ and 4f). Figure 4e shows that mineralization rates increased greatly between June and September. This period corresponded to an increase in TOC in the area (Figure 4f). There was a temporal positive trend between the increase in mineralization rate and the presence of TMZ near Bordeaux (Figure $4 \mathrm{~d}$ and $4 \mathrm{e}$ ). Moreover, the daily average $\mathrm{TOC}_{\mathrm{Ws}}$ showed an increase during spring tides and a settling period at neap tides, corresponding to the POC dynamics (Figure 4e and 4f).

The model showed that degradation of TOC from the watershed $\left(\mathrm{POC}_{\text {litter }}\right.$ and $\left.\mathrm{DOC}_{\text {fluvial }}\right)$ was the main process affecting DO concentration, with an annual average of $50 \%$ oxygen consumption (Figure $4 \mathrm{e}$ ). The inputs of $\mathrm{DOC}_{\text {fluvial }}$ were continuous and contributed $14 \%$ of DO consumption annually. $\mathrm{POC}_{\text {litter }}$ entered the estuary during winter and spring and rapidly 
reached the lower estuary, where it joined the TMZ, which contributed to $36 \%$ of DO consumption annually. During summer, the TMZ moved into the upper estuary, and trapped $\mathrm{POC}_{\text {litter }}$ was the main consumer of DO. The inputs of $\mathrm{POC}_{\text {phyto }}$ and $\mathrm{POC}_{\text {detritus }}$ remained low, even during summer ( $6 \%$ and $2 \%$ of the total DO consumption annually, respectively). Gas exchange was the only process that balanced oxygen, with an annual average input of oxygen of $5.31 \mu \mathrm{mol} \mathrm{L} \mathrm{L}^{-1} \mathrm{~d}^{-1}$. Primary production was very low (due to the high turbidity), with an annual mean oxygen input of $0.04 \mu \mathrm{mol} \mathrm{L}^{-1} \mathrm{~d}^{-1}$.

\subsection{DO dynamics at the Spring-Neap tidal scale}

We focused on the simulation of the period from the $1^{\text {st }}$ to $30^{\text {th }}$ of September 2006, typical of the low discharge season, covering two neap-spring tidal cycles and including two short peaks in river flow (Figure 5b). In the vicinity of Bordeaux, during the two transitions from spring-to-neap tides (i.e., from 09/07 to 09/15 and from 09/20 to 09/25), DO depletion was observed, with the DO minimum occurring a few days after the spring tide peak (evidencing some inertia in the DO response to sediment resuspension), followed by periods of recovery (Figure 5c). Both of these features were well reproduced by the model, as shown by the comparison with observations. During the same spring-to-neap transitions, an increase in SSC due to resuspension by stronger tidal currents was simulated, followed by settling periods during neap tides (Figure 5d). The rates of biogeochemical processes impacting DO and TOC concentrations were calculated over the area including the WWTP and the SO sites of Bordeaux (Figure 1, orange area in lower panel) (Figure 5e and 5f). During neap tides (from $09 / 01$ to $09 / 06$ and from $09 / 14$ to $09 / 21$ ) the $\mathrm{TOC}_{\mathrm{Ws}}$ concentration and the degradation flux were relatively low and aeration was much larger, which resulted in a slight increase of DO, while during spring tides, the opposite was observed (from 09/07 to 09/12 and from $09 / 20$ to $09 / 26$ ). 
After 09/14, there was a strong increase in the Garonne River flow of $\sim 500 \mathrm{~m}^{3} \mathrm{~s}^{-1}$ (Figure $5 b$ ), which lead to an increase in DO of $~ 40 \%$ sat in 3-4 days (Figure 5c). One part of the DO variation is linked to biogeochemical processes and the other part is due to dilution with oxygenated river waters. Considering just the dilution effect on a TMZ with $30 \%$ sat, the concentration of DO will increase by $18 \%$ sat after 4 days with a river flow of $100 \mathrm{~m}^{3} \mathrm{~s}^{-1}$. The observed increase in river flow brought oxygenated water from upstream, which reduced the difference between DOsat and the concentration of DO in the water, and consequently the gas exchange rate (Figure 5e). After the flood period, an increase in mineralization rates occurred, caused by the elevated TOC concentration advected from upstream by the river flow and re-suspended by spring tide currents (Figure 5e and 5f).

A view of the along-channel distribution of simulated variables (Figure 8) shows the spatial structure of hypoxic waters and confirms the patterns observed at Bordeaux in summer. The simulated position of hypoxia persistently occurred near the city of Bordeaux, between 5 and $20 \mathrm{~km}$ from Bec d'Ambès (Figure $8 \mathrm{a}$ and $8 \mathrm{~b}$ ). When the currents intensified, during the spring tide, an upstream shift of hypoxia of less than $5 \mathrm{~km}$ was observed, and a second DO minimum appeared around Portets near the bottom, which was correlated with strong resuspension of deposited POC fixed on SSC, coincident with an increase in POC remineralization (Figure $8 \mathrm{~b}$ and $8 \mathrm{~d}$ ). Thus, during spring tides, hypoxia extends for more than $25 \mathrm{~km}$ between Bordeaux and Portets. Is has to be noted that there is a difference in the vertical distributions of SSC and DO; whilst DO shows more uniformity because of vertical mixing, SSC shows a pronounced vertical gradient and with significantly higher concentration near the bottom (Figure 8). 


\subsection{Impact of wastewater discharge}

From the set of simulations run for 2006, the model showed that the mineralization of TOC from WWTP and SO consumed annually $19 \%$ and $12 \%$ of the DO $\left(-1.05\right.$ and $-0.70 \mu \mathrm{mol} \mathrm{L}^{-1}$ $\mathrm{d}^{-1}$ ), respectively. In this region, nitrification accounted for $11 \%$ of total oxygen consumption on a yearly basis; during summer, nitrification accounted for $18 \%$ of the total oxygen consumption.

To assess the contribution of urban effluents on the oxygen concentration in Bordeaux, we compared the last simulation (presented previously) with a simulation over 10 months that integrated only inputs from the watershed (Figure 9b). In 2006, the SO and WWTP discharged $8.3 \times 10^{6} \mathrm{~m}^{3}$ and $43.1 \times 10^{6} \mathrm{~m}^{3}$ of untreated stormwater and treated wastewater, respectively ( $16 \%$ and $84 \%$ of the total wastewater discharged), into the Garonne River. The difference in simulations with and without urban effluents (Figure 9b) showed that in the Garonne River near Bordeaux, the DO minimum reached 39\%sat in the absence of urban effluents and this was reduced by a further $10 \%$ sat with the addition of urban effluent.

\section{Discussion}

The DO model implemented in the Gironde Estuary achieved the validation criteria specified in section 2.5, including reproduction of the observed DO dynamics and amplitude near the city of Bordeaux at the seasonal and neap-spring tidal time scales (with WSS $=0.77$ Table 3 , c.f. WSS $=0.75$ in $($ Scully, 2013)).

The model results showed that a strong spatial and temporal link exists between the oxygen dynamics and the TMZ, although the SSC and DO were not well correlated all times. As observed in other macro-tidal European estuaries (Talke et al., 2009; Thouvenin et al., 1994), the model results for the Gironde Estuary showed that the POC associated with suspended 
particles contributed to the majority of oxygen consumption, whereas gas exchange with the atmosphere was the major source of DO for the water column. However, in highly turbid estuaries, the presence of suspended sediment particles attenuates the turbulence and therefore slows gas exchange (Abril et al., 2009), accentuating the oxygen deficit in the TMZ. Figure $4 \mathrm{~d}$ showed that the gas exchange rate was lower during periods of higher SSC. Abril et al. (2009) reported two effects of suspended sediment particles on turbulence: 1) the formation of SSC stratification near the bed and consequent turbulence damping and 2) enhanced dissipation of turbulent kinetic energy near the surface because of increasing viscosity.

The biogeochemical model allowed us to simulate the extent of hypoxia in the Garonne River. The low DO zone was persistently centered in front of the city of Bordeaux during the neap tide and spring tide (Figure 8). At spring tide, when the currents increased, the high flood current moved the hypoxic zone upstream from Bordeaux to Portets, and sediment resuspension favored POC degradation. This second DO minimum located around Portets in the bottom waters was caused by the strong resuspension of POC trapped in the fluid mud (Abril et al., 1999) (Figure 8). The influence of SSC on the concentration of DO in the water was also observed during the transition from neap-spring tides (Figure 5). During this period, the POC trapped in the fluid mud earlier during the neap tide was re-suspended in the water column, favoring the degradation of organic matter and decreasing the DO concentration (Abril et al., 1999; Tengberg et al., 2003).

The model results quantify the contribution of urban discharges to estuarine DO depletion. Our result is consistent with the literature, that reports greater hypoxia near large urban areas (Amann et al., 2012; Garnier et al., 2001; Soetaert et al., 2006; Tinsley, 1998; Zhang et al., 2015). In the Gironde Estuary, the same observation was reported by Etcheber et al. (2011) and Lanoux et al. (2013). 
Our model showed DO depletion at Portets due to SSC resuspension during spring tides. The quantity of SSC was lower at Bordeaux than at Portets, although DO depletion at Bordeaux was also enhanced by urban effluents that contributed to oxygen consumption. Because of the modeling approach, we could quantitatively separate the contribution of material from river and urban watersheds to the total DO consumption. Our results showed that at Portets $95 \%$ of DO consumption was due to watershed matter and $4 \%$ to urban water, compared with $58 \%$ and $31 \%$ respectively at Bordeaux.

In the area of Bordeaux, our model showed that the mineralization of TOC from the watershed and WWTP was the main oxygen-consuming process (Figure 4d). Nitrification accounted for only $11 \%$ of the DO consumption (18\% in summer), compared with $50 \%$ of consumption in the Scheldt Estuary (before WWTP improvement; Cox et al., 2009). In the Scheldt Estuary, urban wastewater treatment did not include nitrification, so ammonium concentrations were high. However, in the Gironde Estuary, the reduced nitrogen loads from the rivers are very low and the majority of nitrification is therefore due to WWTP effluents (Lanoux, 2013). The model did not include the production of ammonium by anaerobic remineralization in the fluid mud and may therefore have underestimated $\mathrm{NH}_{4}^{+}$ concentrations in the water column, and the contribution of nitrification to the total oxygen consumption. However, this is unlikely as our modelled $\mathrm{NH}_{4}{ }^{+}$concentrations were consistent with or slightly higher than those measured during the field campaigns in the late 1990s (between 2 and $25 \mu \mathrm{mol} \mathrm{L}{ }^{-1}$ ).

In Bordeaux, we found that with urban effluent input (WWTP and SO), the DO summer mean was $52 \%$ sat $\left(135 \mu \mathrm{mol} \mathrm{L}{ }^{-1}\right.$; without urban input, it was $61 \%$ sat $\left.-157 \mu \mathrm{mol} \mathrm{L}{ }^{-1}\right)$ and the DO minimum was $29 \%$ sat $\left(71 \mu \mathrm{mol} \mathrm{L}{ }^{-1}\right.$; without urban input, it was $39 \%$ sat or $\left.96 \mu \mathrm{mol} \mathrm{L}{ }^{-1}\right)$ (Figure 9b). Further, our simulations summarized in Figure 9c showed that the discharge of treated wastewater from WWTPs alone reduce the minimum DO to $32 \%$ sat (or $78 \mu \mathrm{mol} \mathrm{L}{ }^{-1}$ ), 
and the discharge of untreated wastewater from SOs alone reduced the minimum DO to $36 \%$ sat $\left(88 \mu \mathrm{mol} \mathrm{L}^{-1}\right)$. Consequently, if wastewater management could treat all the urban effluent discharged through the SO, DO would be higher, and low DO events would no longer occur in the Garonne tidal river, resulting in a reduction in biological oxygen stress. The WWTPs provide greater POC and $\mathrm{NH}_{4}{ }^{+}$inputs than $\mathrm{SO}$ (Figure 9c). However, the POC inputs from SO, which represent $16 \%$ of the urban effluent volume discharge, are more labile and impact the DO variation and reduce the DO minimum by 3\%sat. It is therefore necessary to find better solutions to manage wastewater to enhance the oxygenation of the estuary.

The model highlights the sensitivity of water oxygenation to river flow for the oxygenation of water (Table 2), particularly during the most important summer conditions. For accurate model predictions, it is important to monitor DO concentrations upstream in the river as reductions in river DO accentuate hypoxia events. Enhanced primary production in clear river waters might increase river DO and counteract hypoxia near Portets and Bordeaux; however, such blooms supply biodegradable POC to the upstream part of the TMZ. In summer, when the river flow is low, an isolated river flood can increase the DO concentration (Figure 5). Thus, short rain events in the watershed increase river discharge and supply oxygenated freshwater to the upper estuarine area, mitigating hypoxia around Portets. In contrast, summer rain events on the urban area increase organic matter release by sewage overflow and thus enhance oxygen consumption (Even et al., 2007; Mouchel et al., 1994).

\section{Conclusion}

Although the biogeochemical model coupled with a hydro-sedimentary model includes some simplifications (e.g., no consideration of the various classes of phytoplankton and zooplankton and not reproducing the complete nitrogen cycle), we have demonstrated, by comparison with observations, that it can be used with confidence to explore the seasonal 
dynamics of oxygen in Bordeaux and with slightly less confidence further upstream along the Garonne River. Because the presence and intensity of the TMZ determines the temporal and spatial dynamics of DO, including hypoxic events during summer and low Garonne River flow, a 3D fully coupled model was necessary to resolve the system. The influence of SSC on water DO was shown at the seasonal and spring-neap time scales by the intensification of organic carbon degradation in the TMZ and during mud resuspension at spring tide. The hypoxic zone is located near the urbanized city of Bordeaux, which is impacted by urban effluents, and extends to Portets, $25 \mathrm{~km}$ upstream, during spring tides. The comparison of several model scenarios shows that DO depletion is accentuated by both WWTP and SO discharges. Our findings suggest that an active management strategy can reduce POC inputs and increase DO. For example, in our simulations, eliminating SO loads increased the DO minimum in the vicinity of Bordeaux by $3 \%$ sat; omitting all urban effluents (SO and WWTP) increased the DO minimum in the vicinity of Bordeaux by $10 \%$ sat and mitigated hypoxic events. To improve the oxygenation of the water, our DO model could be used as a tool to inform managers of useful future directions, and management scenarios could be tested to assess the quality, quantity and location of wastewater discharge.

Climate change projections for the Gironde Estuary, include a decrease in river flow, sea level rise and an increase in water temperature (Etcheber et al., 2013). Variations in river flow and sea level could affect the location of the TMZ, and an increase in the water temperature could affect the biogeochemical flux rates. In this context, the proposed biogeochemical model could be used to further investigate the impact of climate change on the oxygenation of the waters of the Gironde Estuary. 


\section{Acknowledgments}

This study was funded by the Aquitaine Region and LyRE (SUEZ Research Center), who provided $\mathrm{PhD}$ grants to $\mathrm{K}$. Lajaunie-Salla. This research was also supported by the Cluster of Excellence COTE at the Universite de Bordeaux (ANR-10-LABX-45). The authors are also grateful to the MAGEST network for providing the data and to Guillaume Binet for providing urban effluent data and fruitful discussion. 


\section{References}

Abril, G., Commarieu, M.V., Etcheber, H., Deborde, J., Deflandre, B., Živadinović, M.K., Chaillou, G., Anschutz, P., 2010. In vitro simulation of oxic/suboxic diagenesis in an estuarine fluid mud subjected to redox oscillations. Estuar. Coast. Shelf Sci. 88, 279291. doi:10.1016/j.ecss.2010.04.003

Abril, G., Commarieu, M.V., Sottolichio, A., Bretel, P., Guérin, F., 2009. Turbidity limits gas exchange in a large macrotidal estuary. Estuar. Coast. Shelf Sci. 83, 342-348. doi:10.1016/j.ecss.2009.03.006

Abril, G., Etcheber, H., Le Hir, P., Bassoullet, P., Boutier, B., Frankignoulle, M., 1999. Oxic/anoxic oscillations and organic carbon mineralization in an estuarine maximum turbidity zone (The Gironde, France). Limnol. Oceanogr. 44, 1304-1315.

Abril, G., Nogueira, M., Etcheber, H., Cabeçadas, G., Lemaire, E., Brogueira, M.J., 2002. Behaviour of Organic Carbon in Nine Contrasting European Estuaries. Estuar. Coast. Shelf Sci. 54, 241-262. doi:10.1006/ecss.2001.0844

Abril, G., Riou, S. a., Etcheber, H., Frankignoulle, M., de Wit, R., Middelburg, J.J., 2000. Transient, Tidal Time-scale, Nitrogen Transformations in an Estuarine Turbidity Maximum-Fluid Mud System (The Gironde, South-west France). Estuar. Coast. Shelf Sci. 50, 703-715. doi:10.1006/ecss.1999.0598

Allen, G.P., 1972. Étude des processus sédimentaires dans l'estuaire de la Gironde. Université de Bordeaux.

Allen, G.P., Salomon, J., Bassoullet, P., 1980. Effects of tides on mixing and suspended sediment transport in macrotidal estuaries. Sediment. Geol. 26, 69-90.

Amann, T., Weiss, A., Hartmann, J., 2012. Carbon dynamics in the freshwater part of the Elbe estuary, Germany: Implications of improving water quality. Estuar. Coast. Shelf Sci. 107, 112-121. doi:10.1016/j.ecss.2012.05.012

Ambrose, R.B., Wool, T.A., Martin, J.L., 1993. The water quality analysis simulation program, WASP5 part A: Model Documentation.

Benaouda, A., 2008. Dynamique saisonniere des sediments en suspension dans l'estuaire de la Gironde: Modelisation operationnelle de la reponse aux forçages hydrodynamiques. Université de Bordeaux.

Billen, G., Garnier, J., Hanset, P., 1994. Modelling phytoplankton development in whole drainage networks: the RIVERSTRAHLER Model applied to the Seine river system. Hydrobiologia 289, 119-137.

Brenon, I., Le Hir, P., 1999. Modelling the Turbidity Maximum in the Seine Estuary (France): Identification of Formation Processes. Estuar. Coast. Shelf Sci. 49, 525-544. doi:10.1006/ecss.1999.0514

Brock, T.D., 1981. Calculating solar radiation for ecological studies. Ecol. Modell. 14, 1-19.

Bruce, L.C., Cook, P.L.M., Teakle, I., Hipsey, M.R., 2014. Hydrodynamic controls on oxygen dynamics in a riverine salt wedge estuary, the Yarra River estuary, Australia. Hydrol. Earth Syst. Sci. 18, 1397-1411. doi:10.5194/hess-18-1397-2014

Carmichael, G.R., Sandu, A., Potra, F.A., 1995. Sensitivity analysis for atmospheric chemistry models via automatic differentiation. Atmospheri 31, 475-489. 
Castaing, P., Allen, G.P., 1981. Mechanisms controlling seaward escape of suspended sediment from the Gironde: A macrotidal estuary in France. Mar. Geol. 40, 101-118. doi:10.1016/0025-3227(81)90045-1

Conley, D.J., Carstensen, J., Vaquer-Sunyer, R., Duarte, C.M., 2009. Ecosystem thresholds with hypoxia. Hydrobiologia 629, 21-29. doi:10.1007/s 10750-009-9764-2

Cox, T.J.S., Maris, T., Soetaert, K., Conley, D.J., Van Damme, S., Meire, P., Middelburg, J.J., Vos, M., Struyf, E., 2009. A macro-tidal freshwater ecosystem recovering from hypereutrophication: the Schelde case study. Biogeosciences 6, 2935-2948. doi:10.5194/bg-6-2935-2009

Cugier, P., 1999. Modélisation du devenir à moyen terme dans l'eau et le sédiment des éléments majeurs (N, P, Si) rejetés par la Seine en Baie de Seine. Universite de Caen/Basse Normandie.

Cugier, P., Le Hir, P., 2002. Development of a 3D Hydrodynamic Model for Coastal Ecosystem Modelling. Application to the Plume of the Seine River (France). Estuar. Coast. Shelf Sci. 55, 673-695. doi:10.1006/ecss.2001.0875

Di Toro, D.M., Thomann, R. V., O’Connor, D.J., Mancini, J.L., 1977. Estuarine phytoplankton biomass models verification analyses and preliminary applications.

Diaz, R.J., 2001. Overview of hypoxia around the world. J. Environ. Qual. 30, 275-281. doi:10.2134/jeq2001.302275x

Diaz, R.J., Rosenberg, R., 2008. Spreading dead zones and consequences for marine ecosystems. Science (80-. ). 321, 926-929. doi:10.1126/science.1156401

Doxaran, D., Froidefond, J.M., Castaing, P., Babin, M., 2009. Dynamics of the turbidity maximum zone in a macrotidal estuary (the Gironde, France): observations from field and MODIS satellite data. Estuar. Coast. Shelf Sci. 81, 321-332. doi:http://dx.doi.org/10.1016/j.ecss.2008.11.013

Etcheber, H., Coupry, B., Coynel, A., Sauquet, E., Baron, J., Bernard, C., Cuende, F.X., Leurent, T., 2013. Disponibility of surficial continental waters, in: Le Treut, H. (Ed.), Impact of Climate Change in the Aquitaine Region. Scientific Report. Pessac, p. 365.

Etcheber, H., Schmidt, S., Sottolichio, A., Maneux, E., Chabaux, G., Escalier, J.-M., Wennekes, H., Derriennic, H., Schmeltz, M., Quéméner, L., Repecaud, M., Woerther, P., Castaing, P., 2011. Monitoring water quality in estuarine environments: lessons from the MAGEST monitoring program in the Gironde fluvial-estuarine system. Hydrol. Earth Syst. Sci. 15, 831-840. doi:10.5194/hess-15-831-2011

Etcheber, H., Taillez, A., Abril, G., Garnier, J., Servais, P., Moatar, F., Commarieu, M.-V., 2007. Particulate organic carbon in the estuarine turbidity maxima of the Gironde, Loire and Seine estuaries: origin and lability. Hydrobiologia 588, 245-259. doi:10.1007/s10750-007-0667-9

Even, S., Mouchel, J.M., Servais, P., Flipo, N., Poulin, M., Blanc, S., Chabanel, M., Paffoni, C., 2007. Modelling the impacts of Combined Sewer Overflows on the river Seine water quality. Sci. Total Environ. 375, 140-151. doi:10.1016/j.scitotenv.2006.12.007

Garnier, J., Servais, P., Billen, G., Akopian, M., Brion, N., 2001. Lower Seine River and Estuary (France) Carbon and Oxygen Budgets during Low Flow. Estuaries 24, 964-976. doi:10.2307/1353010

Gray, J.S., Wu, R.S., Or, Y.Y., 2002. Effects of hypoxia and organic enrichment on the 
coastal marine environment. Mar. Ecol. Prog. Ser. 238, 249-279. doi: $10.3354 /$ meps 238249

Hadley, S., Wild-Allen, K., Johnson, C., Macleod, C., 2015. Modeling macroalgae growth and nutrient dynamics for integrated multi-trophic aquaculture. J. Appl. Phycol. 27, 901-916. doi:10.1007/s10811-014-0370-y

Hagy, J.D., Boynton, W.R., Keefe, C.W., Wood, K. V., 2004. Hypoxia in Chesapeake Bay, 1950-2001: Long-term change in relation to nutrient loading and river flow. Estuaries 27, 634-658. doi:10.1007/BF02907650

Irigoien, X., Castel, J., 1997. Light limitation and distribution of chlorophyll pigments in a highly turbid estuary: The Gironde (SW France). Estuar Coast Shelf Sci 44, 507-517. doi:10.1006/ecss.1996.0132

Jähne, B.J., Münnich, K.O.M., Bösinger, R., Dutzi, A., Huber, W., Libner, P., 1987. On the Parameters Influencing Air-Water Gas Exchange of magnitude lower in the water than in the air , information, which in turn has also hindered transfer in the water $\mathrm{k}+$. J. Geophys. Res. 92, 1937-1949. doi:10.1029/JC092iC02p01937

Jalón-Rojas, I., Schmidt, S., Sottolichio, A., 2015. Turbidity in the fluvial Gironde Estuary (southwest France) based on 10-year continuous monitoring: sensitivity to hydrological conditions. Hydrol. Earth Syst. Sci. 19, 2805-2819. doi:10.5194/hess-19-2805-2015

Jouanneau, J.M., Latouche, C., 1981. The Gironde Estuary, in: Fürchtbauer, H., Lisitzyn, A.P., Millerman, J.D., Seibold, E. (Eds.), Contribution to Sedimentology. pp. 1-115.

Justić, D., Bierman Jr., V.J., Scavia, D., Hetland, R.D., 2007. Forecasting Gulf' s Hypoxia : The Next 50 Years? Estuaries and Coasts 30, 791-801.

Kemp, W.M., Testa, J.M., Conley, D.J., Gilbert, D., Hagy, J.D., 2009. Temporal responses of coastal hypoxia to nutrient loading and physical controls. Biogeosciences 6, 2985-3008. doi:10.5194/bg-6-2985-2009

Krone, R.B., 1962. Flume studies of the transport of sediment in estuarial shoaling processes; final report. Hydraulic Engineering Laboratory and Sanitary Engineering Research Laboratory, University of California, University of California, Berkeley.

Lanoux, A., 2013. Caratérisation et rôle respectif des apports organiques amont et locaux sur l'oxygènation des eaux de la Garonne estuarienne. Université de Bordeaux.

Lanoux, A., Etcheber, H., Schmidt, S., Sottolichio, A., Chabaud, G., Richard, M., Abril, G., 2013. Factors contributing to hypoxia in a highly turbid, macrotidal estuary (the Gironde, France). Environ. Sci. Process. Impacts 15, 585-595. doi:10.1039/c2em30874f

Le Hir, P., Bassoullet, P., Jestin, H., 2000. Application of the continuous modeling concept to simulate high-concentration suspended sediment in a macrotidal estuary, in: Science, W.H.M. and A.J.M.B.T.-P. in M. (Ed.), Coastal and Estuarine Fine Sediment Processes. Elsevier, pp. 229-247. doi:http://dx.doi.org/10.1016/S1568-2692(00)80124-2

Lemaire, E., 2002. Biomarqueurs pigmentaires dans les estuaires macrotidaux européens. Ec. Dr. des Sci. du vivant, géosciences Sci. l'environnement Doctorat, 236.

Lemaire, E., Abril, G., De Wit, R., Etcheber, H., 2002. Effet de la turbidité sur la dégradation des pigments phytoplanctoniques dans l'estuaire de la Gironde. Geoscience 334, $251-$ 258.

Li, D., Zhang, J., Huang, D., WU, Y., Liang, J., 2002. Oxygen depletion off the Changjiang (Yangtze River) Estuary. Sci. China Ser. D 45, 1137. doi:10.1360/02yd9110 
Lopes, J.F., Silva, C., 2006. Temporal and spatial distribution of dissolved oxygen in the Ria de Aveiro lagoon. Ecol. Modell. 197, 67-88. doi:10.1016/j.ecolmodel.2006.03.012

Lopes, J.F., Silva, C.I., Cardoso, A.C., 2008. Validation of a water quality model for the Ria de Aveiro lagoon, Portugal. Environ. Model. Softw. 23, 479-494. doi:10.1016/j.envsoft.2007.07.001

Middelburg, J.J., Herman, P.M.J., 2007. Organic matter processing in tidal estuaries. Mar. Chem. 106, 127-147. doi:10.1016/j.marchem.2006.02.007

Mouchel, J.-M., Simon, L., Maldiney, M.-A., 1994. Impacts en seine des rejets urbains de temps de pluie sur les concentrations d'oxygene dissous. La Houille Blanche 1, 135141.

Partheniades, E., 1965. Erosion and deposition of cohesive soils. J. Hydraul. Div. 91, 105139.

Rabalais, N.N., Levin, L.A., Turner, R.E., Gilbert, D., Zhang, J., 2010. Dynamics and distribution of natural and human-caused coastal hypoxia. Biogeosciences 7, 585-619. doi:10.5194/bgd-6-9359-2009

Regnier, P., Steefel, C.I., 1999. A high resolution estimate of the inorganic nitrogen flux from the Scheldt estuary to the coastal North Sea during a nitrogen-limited algal bloom, spring 1995. Geochim. Cosmochim. Acta 63, 1359-1374.

Rykiel, E.J., 1996. Testing ecological models: The meaning of validation. Ecol. Modell. 90, 229-244. doi:10.1016/0304-3800(95)00152-2

Saari, H.K., Schmidt, S., Castaing, P., Blanc, G., Sautour, B., Masson, O., Cochran, J.K., 2010. The particulate $7 \mathrm{Be} / 210 \mathrm{Pbxs}$ and $234 \mathrm{Th} / 210 \mathrm{Pbxs}$ activity ratios as tracers for tidal-to-seasonal particle dynamics in the Gironde estuary (France): Implications for the budget of particle-associated contaminants. Sci. Total Environ. 408, 4784-4794. doi:10.1016/j.scitotenv.2010.07.017

Schmidt, S., Etcheber, H., Sottolichio, A., Castaing, P., 2016. Le réseau MAGEST: bilan de 10 ans de suivi haute-fréquence de la qualité des eaux de l'estuaire de la Gironde, in: Schmitt, F.G., Lefevre, A. (Eds.), Mesures Haute Résolution Dans L'environnement Marin Côtier. Presses du CNRS.

Scully, M.E., 2013. Physical controls on hypoxia in Chesapeake Bay: A numerical modeling study. J. Geophys. Res. Ocean. 118, 1239-1256. doi:10.1002/jgrc.20138

Skerratt, J., Wild-Allen, K., Rizwi, F., Whitehead, J., Coughanowr, C., 2013. Use of a high resolution 3D fully coupled hydrodynamic, sediment and biogeochemical model to understand estuarine nutrient dynamics under various water quality scenarios. Ocean Coast. Manag. 83, 52-66. doi:10.1016/j.ocecoaman.2013.05.005

Soetaert, K., Middelburg, J.J., Heip, C., Meire, P., Van, S., Maris, T., Damme, S. Van, 2006. Long-term change in dissolved inorganic nutrients in the heterotrophic Scheldt estuary (Belgium, The Netherlands). Limnol. Oceanogr. 51, 409-423.

Sottolichio, A., Castaing, P., 1999. A synthesis on seasonal dynamics of highly concentrated structures in the Gironde estuary. Comptes Rendus l'Academie Sci. - Ser. IIa Sci. la Terre des Planetes 329, 795-800. doi:doi:10.1016/S1251- 8050(00)88634-6

Sottolichio, A., Hir, P. Le, Castaing, P., 2000. Modeling mechanisms for the stability of the turbidity maximum in the Gironde estuary, France. Proc. Mar. Sci. 3, 373-386.

Steele, J.H., 1962. Environmental control of photosynthesis in the sea. Limnol. Ocean. 7, 
$137-150$.

Talke, S. a., Swart, H.E., Jonge, V.N., 2009. An Idealized Model and Systematic Process Study of Oxygen Depletion in Highly Turbid Estuaries. Estuaries and Coasts 32, 602620. doi:10.1007/s12237-009-9171-y

Tengberg, a, Almroth, E., Hall, P., 2003. Resuspension and its effects on organic carbon recycling and nutrient exchange in coastal sediments: in situ measurements using new experimental technology. J. Exp. Mar. Bio. Ecol. 285-286, 119-142. doi:10.1016/S0022-0981(02)00523-3

Thouvenin, B., Le Hir, P., Romana, L.A., 1994. Dissolved oxygen model in the Loire estuary. Chang. fluxes estuaries Implica- tions from Sci. to Manag. Acad. 169-178.

Tinsley, D., 1998. The Thames estuary: a history of the impact of humans on the environment and a description of the current approach to environmental management, in: Attrill, $\mathrm{M}$. (Ed.), A Rehabilitated Estuarine Ecosystem SE - 2. Springer US, pp. 5-26. doi:10.1007/978-1-4419-8708-2_2

Van Maanen, B., Sottolichio, A., 2013. Hydro- and sediment dynamics in the Gironde estuary (France): Model validation and sea level rise effects. Coast. Dyn.

Vanderborght, J.-P., Folmer, I.M., Aguilera, D.R., Uhrenholdt, T., Regnier, P., 2007. Reactive-transport modelling of $\mathrm{C}, \mathrm{N}$, and $\mathrm{O} 2$ in a river-estuarine-coastal zone system: Application to the Scheldt estuary. Mar. Chem. 106, 92-110. doi:10.1016/j.marchem.2006.06.006

Verity, P.G., Alber, M., Bricker, S.B., 2006. Development of Hypoxia in Well-mixed Subtropical Estuaries in the Southeastern USA. Estuaries and Coasts 29, 665-673.

Veyssy, E., 1998. Transferts de matière organiques das bassins versants aux estuaires de la Gironde et de l'Adour (Sud-Ouest de la France). Université de Bordeaux.

Villate, F., Iriarte, A., Uriarte, I., Intxausti, L., de la Sota, A., 2013. Dissolved oxygen in the rehabilitation phase of an estuary: influence of sewage pollution abatement and hydroclimatic factors. Mar. Pollut. Bull. 70, 234-46. doi:10.1016/j.marpolbul.2013.03.010

Wanninkhof, R., 1992. Relationship Between Wind Speed and Gas Exchange. J. Geophys. Res. 97, 7373-7382.

Wild-Allen, K., Herzfeld, M., Thompson, P. a., Rosebrock, U., Parslow, J., Volkman, J.K., 2009. Applied coastal biogeochemical modelling to quantify the environmental impact of fish farm nutrients and inform managers. J. Mar. Syst. 81, 134-147. doi:10.1016/j.jmarsys.2009.12.013

Willmott, C.J., 1982. Some comments on the evaluation of model performance. Bull. Am. Meteorol. Soc. 63.

Xue, P., Chen, C., Qi, J., Beardsley, R.C., Tian, R., Zhao, L., Lin, H., 2014. Mechanism studies of seasonal variability of dissolved oxygen in Mass Bay: A multi-scale FVCOM/UG-RCA application. J. Mar. Syst. 131, 102-119. doi:10.1016/j.jmarsys.2013.12.002

Zhang, P., Pang, Y., Pan, H., Shi, C., Huang, Y., Wang, J., 2015. Factors Contributing to Hypoxia in the Minjiang River Estuary, Southeast China. Int. J. Environ. Res. Public Health 12, 9357-9374. doi:10.3390/ijerph120809357

Zheng, L., Chen, C., Zhang, F.Y., 2004. Development of water quality model in the Satilla River Estuary, Georgia. Ecol. Modell. 178, 457-482. 
doi:10.1016/j.ecolmodel.2004.01.016

Zouiten, H., Díaz, C.Á., Gómez, A.G., Cortezón, J.A.R., Alba, J.G., 2013. An advanced tool for eutrophication modeling in coastal lagoons: Application to the Victoria lagoon in the north of Spain. Ecol. Modell. 265, 99-113. doi:10.1016/j.ecolmodel.2013.06.009 
Table 1: Boundary conditions and point source concentration for each variable in $\mu \mathrm{mol} \mathrm{L} \mathrm{L}^{-1}$. j=January, $\mathrm{m}=$ May and $\mathrm{s}=$ September.

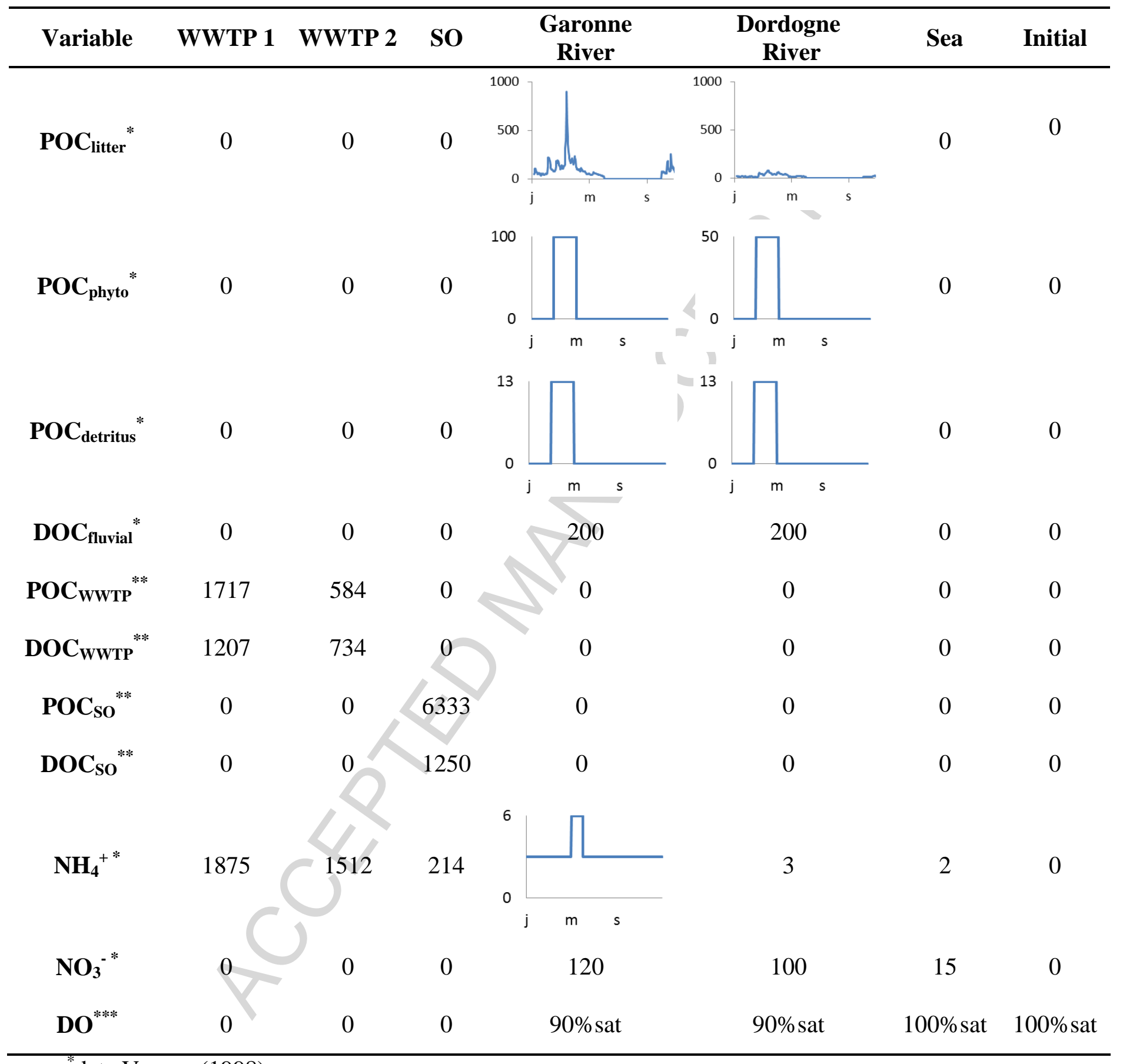

*data Veyssy (1998).

** data from Lanoux (2013)

**** data from MAGEST 
Table 2: Sensitivity of modelled DO concentration in Bordeaux to parameter variation

\begin{tabular}{cccccccc}
\hline Parameters & $\mathbf{k}_{\mathbf{P}}^{\text {SO }}$ & $\mathbf{k}_{\mathbf{P}}^{\text {WWTP }}$ & $\mathbf{k}_{\mathbf{P}}^{\text {litter }}$ & $\mathbf{k}_{\mathbf{D}}^{\text {fluvial }}$ & $\mathbf{k}_{\text {nit }}$ & $\mathbf{U}_{\mathbf{1 0}}$ & DO rivers \\
\hline Perturbation & $\begin{array}{c} \pm 0.1 \mathrm{~d}^{-1} \\
\text { or } 25 \%\end{array}$ & $\begin{array}{c} \pm 0.07 \mathrm{~d}^{-1} \\
\text { or } 23 \%\end{array}$ & $\begin{array}{c} \pm 0.0005 \mathrm{~d}^{-1} \\
\text { or } 10 \%\end{array}$ & $\begin{array}{c} \pm 0.0005 \mathrm{~d}^{-1} \\
\text { or } 10 \%\end{array}$ & $\begin{array}{c} \pm 0.01 \mathrm{~d}^{-1} \\
\text { or } 10 \%\end{array}$ & $\pm 10 \%$ & $\begin{array}{c} \pm 10 \% \text { sat } \\
\text { or } \pm 11 \%\end{array}$ \\
$\begin{array}{c}\text { S1: Sensitivity } \\
\text { of DO mean }\end{array}$ & -0.002 & -0.003 & -0.05 & -0.019 & -0.011 & 0.069 & $0.646^{*}$ \\
$\begin{array}{c}\text { S2: Sensitivity } \\
\text { of DO min }\end{array}$ & -0.038 & -0.008 & $-0.620^{*}$ & -0.134 & -0.096 & $0.370^{*}$ & $1.196^{*}$ \\
\hline
\end{tabular}

*The absolute value of 0.3 is considered as the threshold for the model to be sensitive to that parameter Hadley et al. (2015) 
Table 3: Statistical validation table for 2005-2006, $N=$ number of measurements, WSS = Wilmott Skill Score. Units of bias are in the units of the parameters: water level in $\mathrm{m}, \mathrm{SSc}$ in $\mathrm{g} \mathrm{L}^{-1}$ and DO in \% sat

\begin{tabular}{l|ccccc}
\hline & & $\begin{array}{c}\text { Water } \\
\text { level }\end{array}$ & Salinity & SSC & DO \\
\hline Bordeaux & $\mathrm{N}$ & 394733 & 62230 & 62294 & 62220 \\
& Bias & 0.07 & -0.68 & -0.76 & 10.26 \\
& WSS & 0.93 & 0.78 & 0.53 & 0.77 \\
& $\mathrm{~N}$ & $/$ & 57726 & 60869 & 45811 \\
& Bias & $/$ & -0.12 & -0.44 & -4.27 \\
& WSS & $/$ & 0.38 & 0.33 & 0.39 \\
\hline
\end{tabular}


Figure 1: The Gironde Estuary in Southwest France. Transect distances along the estuary are noted by kilometric points (PK), where the origin (PK0) is in Bordeaux (the monitoring station is located at PK4), PK100 at the mouth and PK-70 is the upstream limit of tide propagation. The red points represent the monitoring stations. The area in orange represents the area of Bordeaux, where the rates of biogeochemical processes were calculated. The purple line represents the $200 \mathrm{~m}$ isobath.

Figure 2: Schematic of the biogeochemical model developed for the Gironde Estuary.

Figure 3: Observed versus simulated variables in Bordeaux for 2005 and 2006: (a) water level in $\mathrm{m}$, (b) salinity, (c) SSC in $\mathrm{g} \mathrm{L}^{-1}$ and (d) DO in \%sat.

Figure 4: Temporal evolution between the $1^{\text {st }}$ of January and $31^{\text {st }}$ of October 2006 at Bordeaux of: temperature (a), river flow in $\mathrm{m}^{3} \mathrm{~s}^{-1}(\mathrm{~b})$, simulated (blue) and observed (green) DO concentration at the surface in $\%$ sat (c), and SSC at the surface in $\mathrm{g} \mathrm{L}^{-1}$ (d). The daily average rates of biogeochemical process affecting DO in $\mu \mathrm{mol} \mathrm{L^{-1 }} \mathrm{d}^{-1}$ calculated in the vicinity of Bordeaux (the orange area in lower panel of the figure 1): mineralization of TOC (POC+DOC) from WS (green), SO (blue), WWTP (magenta), nitrification (cyan) and

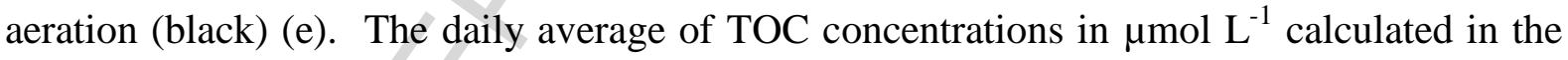
vicinity of Bordeaux (the orange area in lower panel of the figure 1): from WS (green), SO (blue) and WWTP (magenta) (f). Please note that SSC reaches a maximum value of 5.7 g. $\mathrm{L}^{-1}$, because the turbidity sensors were saturated at the constant value of 9999 NTU in summer.

Figure 5: Temporal evolution during September 2006 at Bordeaux of: temperature (a), water level in $\mathrm{m}$ (blue) and river flow in $\mathrm{m}^{3} \mathrm{~s}^{-1}$ (green) (b), simulated (blue) and observed (green) DO concentrations at the surface in \%sat (c), and SSC at the surface in $\mathrm{g} \mathrm{L}^{-1}$ (d). The rates of biogeochemical processes affecting DO in $\mu \mathrm{mol} \mathrm{L}^{-1} \mathrm{~d}^{-1}$ calculated in the vicinity of Bordeaux (the orange area in lower panel of the figure 1): mineralization of TOC (POC+DOC) from 
WS (green), SO (blue), WWTP (magenta), nitrification (cyan) and aeration (black) (e). The TOC concentrations calculated in the vicinity of Bordeaux (the orange area in lower panel of the figure 1): from WS (green), SO (blue) and WWTP (magenta) (f). Please note that SSC reaches a maximum value of 5.7 g. $\mathrm{L}^{-1}$, because the turbidity sensors were saturated at the constant value of 9999 NTU in summer.

Figure 6: Simulated distribution of the maximum near-bottom SSC in $\mathrm{g} \mathrm{L}^{-1}$ (top) and minimum surface DO in \%sat (bottom) during February 2006 (left) and July 2006 (right).

Figure 7: Vertical profile of the temporal evolution between the $1^{\text {st }}$ of January and the $31^{\text {st }}$ of October 2006 at Bordeaux of: river discharge in $\mathrm{m}^{3} \mathrm{~s}^{-1}$ (a), simulated daily average DO in \%sat (b), SSC in $\mathrm{g} \mathrm{L}^{-1}$ (c) and salinity in psu (d).

Figure 8: Snapshot of the vertical transect of simulated DO concentration in \%sat (top) and $\mathrm{SSC}$ in $\mathrm{g} \mathrm{L}^{-1}$ (bottom) along the Garonne tidal river (the central mesh) during high neap tide (NT) and high spring tide (ST). P1, P2 and P3 indicate the locations of Bec d'Ambès, Bordeaux and Portets, respectively.

Figure 9: (a) River flow discharge. (b) Comparison of two simulations of DO variation in $\%$ sat at Bordeaux between the $1^{\text {st }}$ of January and $31^{\text {st }}$ of October 2006: Inputs from WS only (green), Inputs from WS, WWTP and SO (blue). (c) DO minimum (\%sat) as a function of POC input (tC/10 months): simulation 1 reference: inputs from WS, simulation 2: inputs from WS and SO, simulation 3: inputs from WS and WWTP, simulation 4: inputs from WS, WWTP and SO. 
Figure 1:

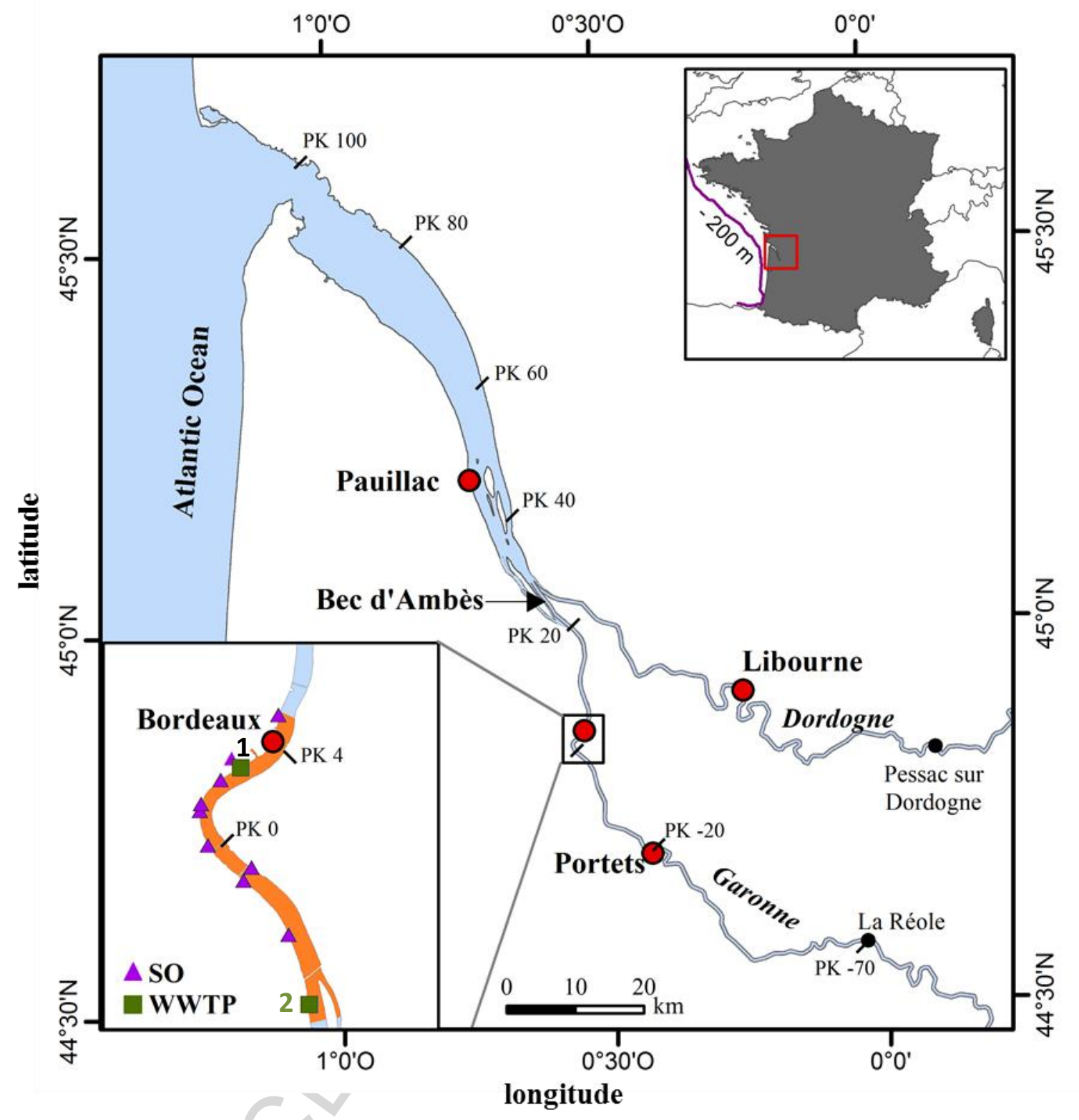


Figure 2:

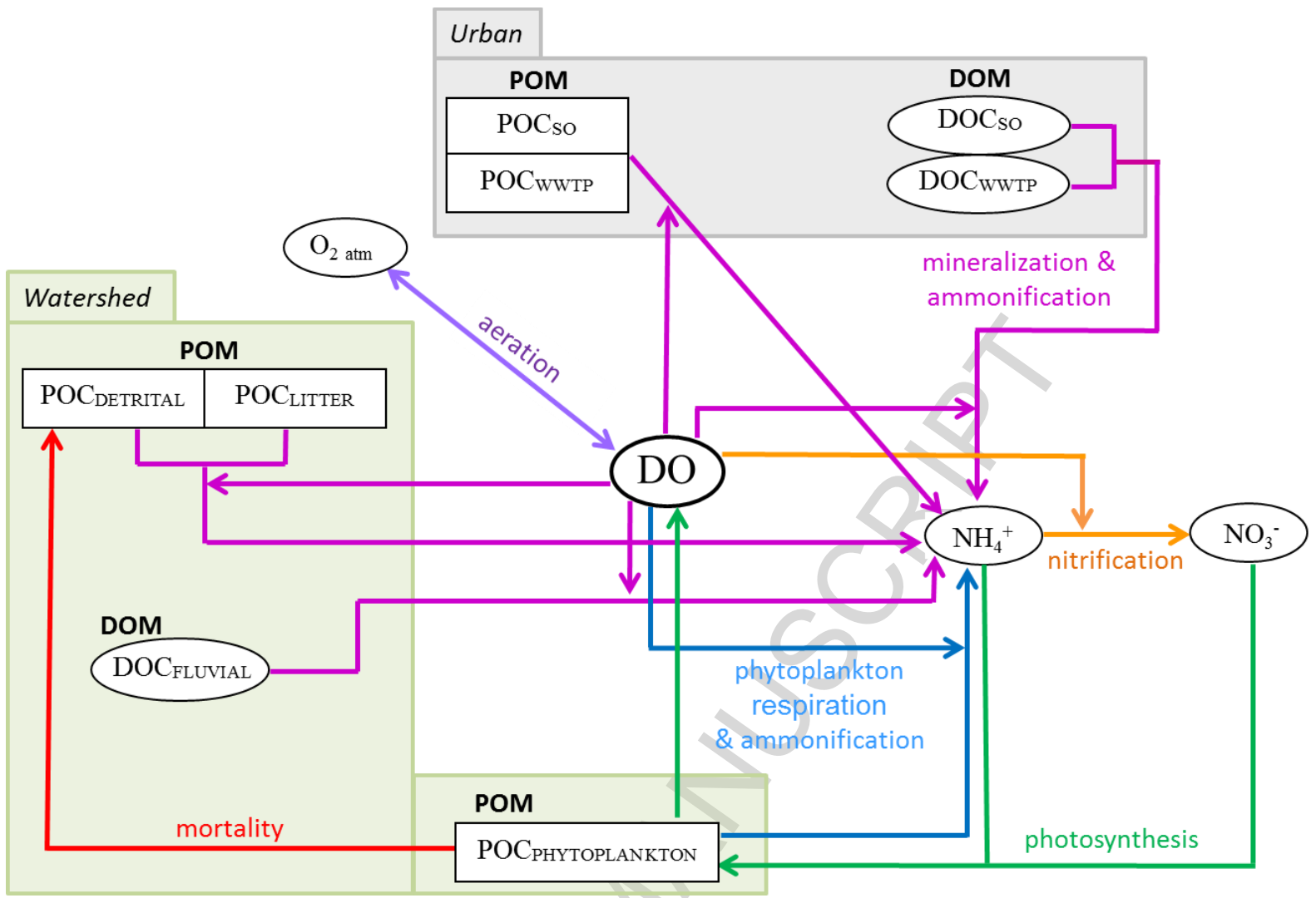


Figure 3
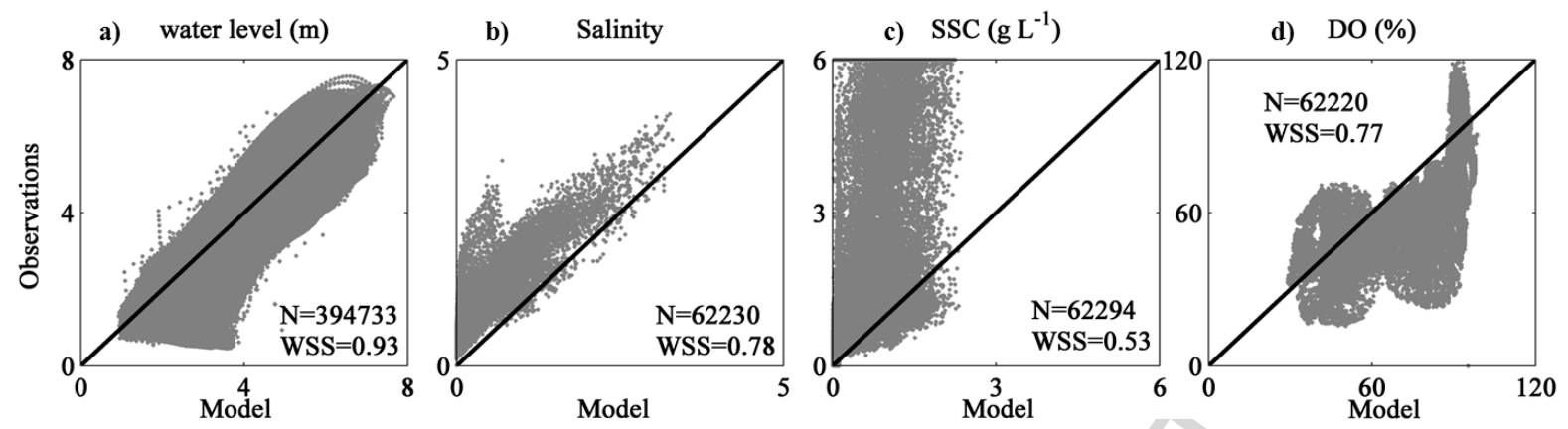
Figure 4:
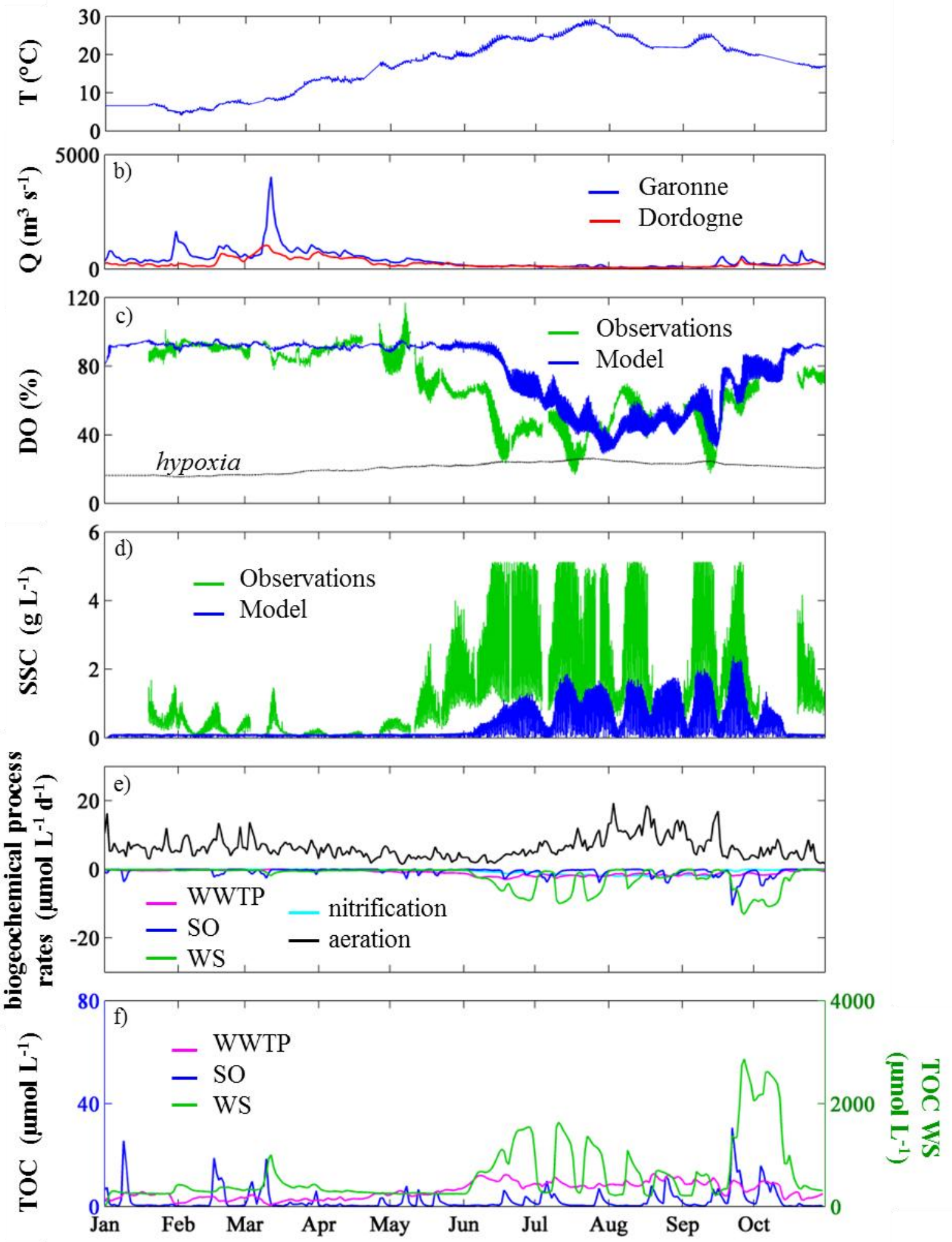
Figure 5:
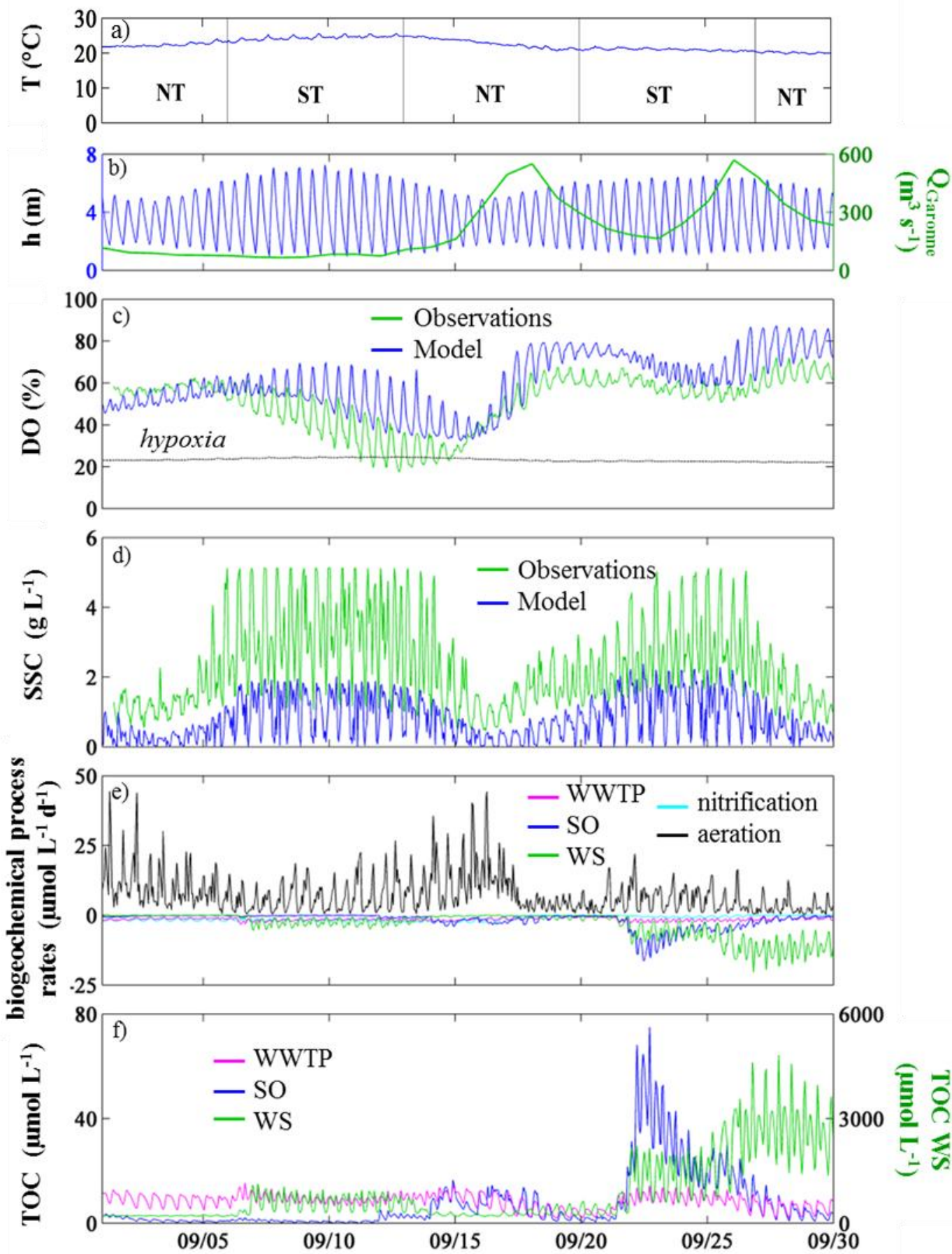
Figure 6

February
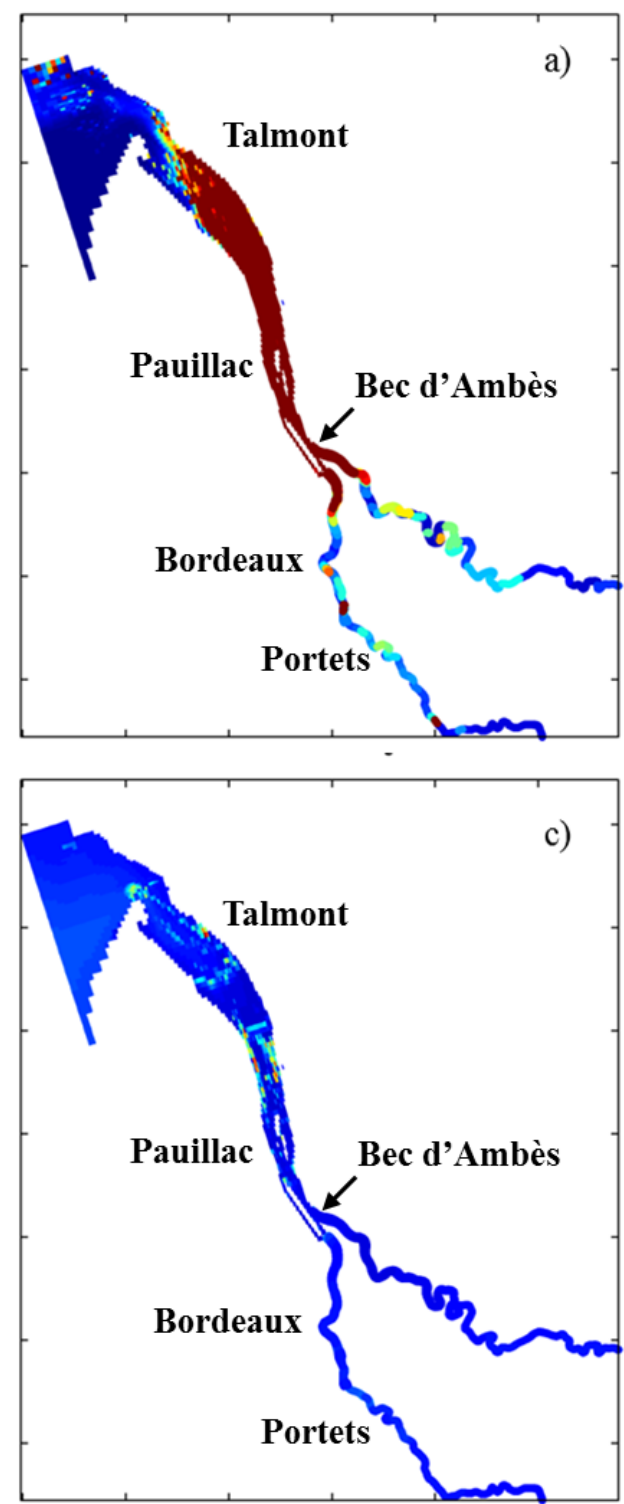

July
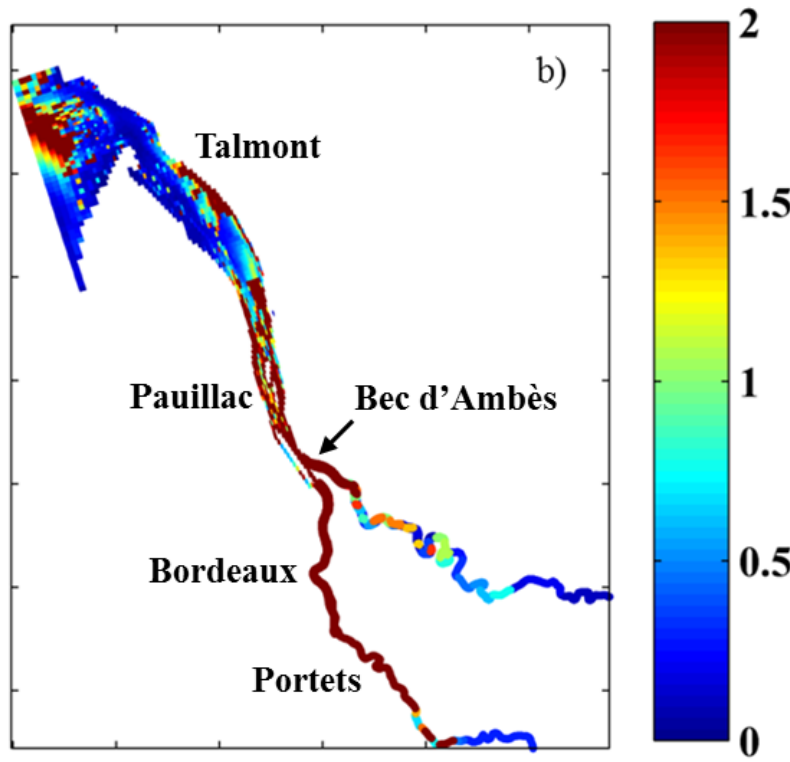

1.5

ลิ

0.5

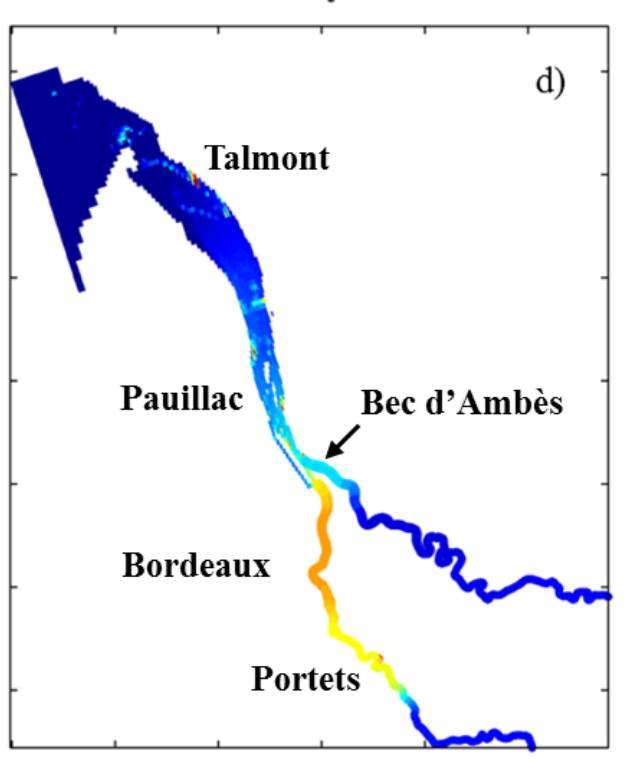

100

80

60

อ

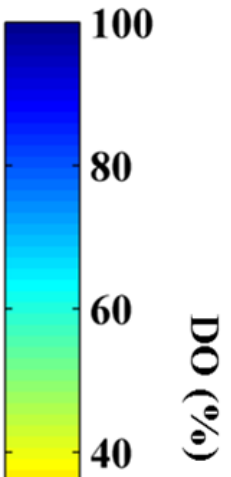

20

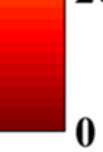


Figure 7
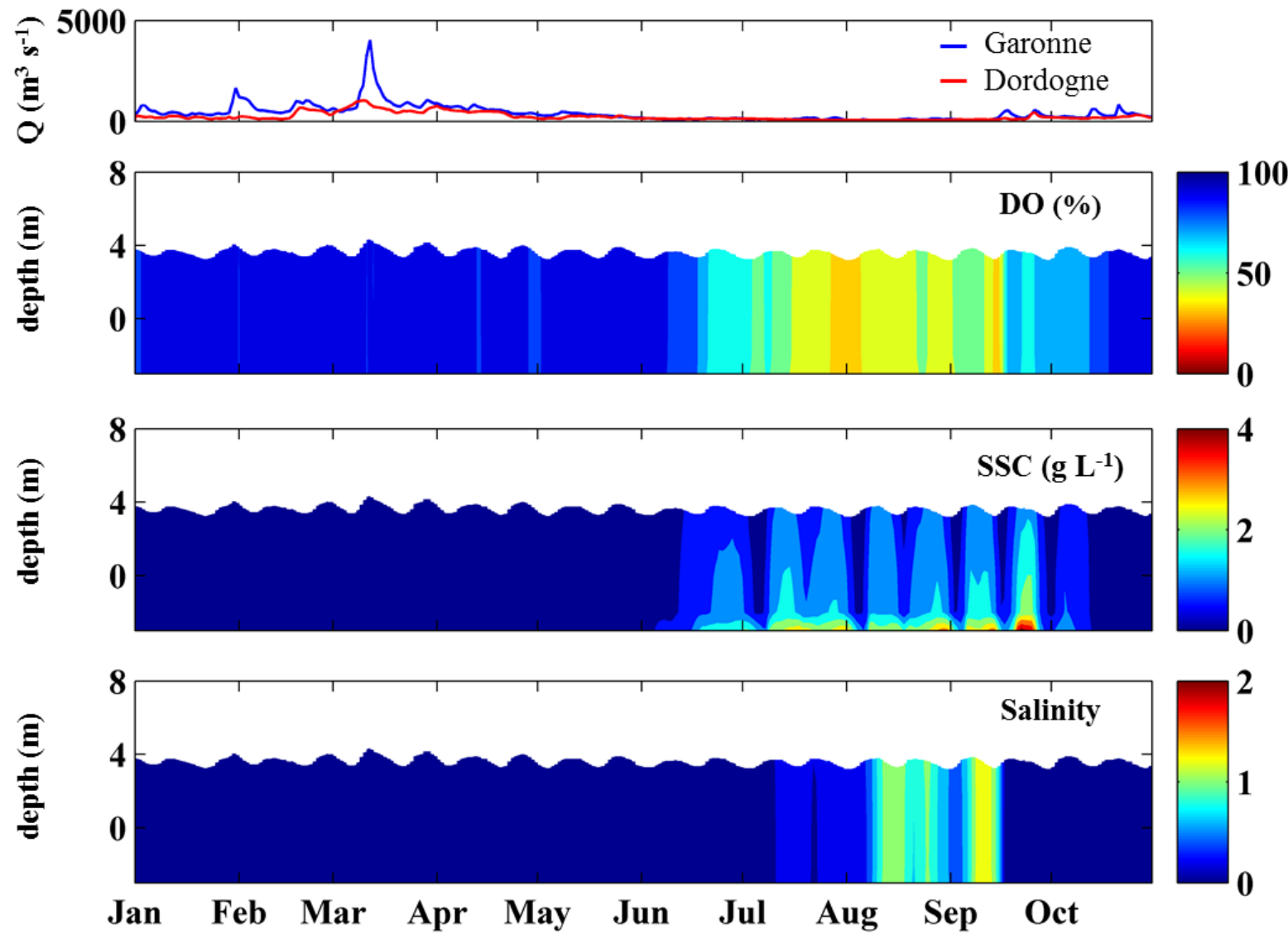
Figure 8
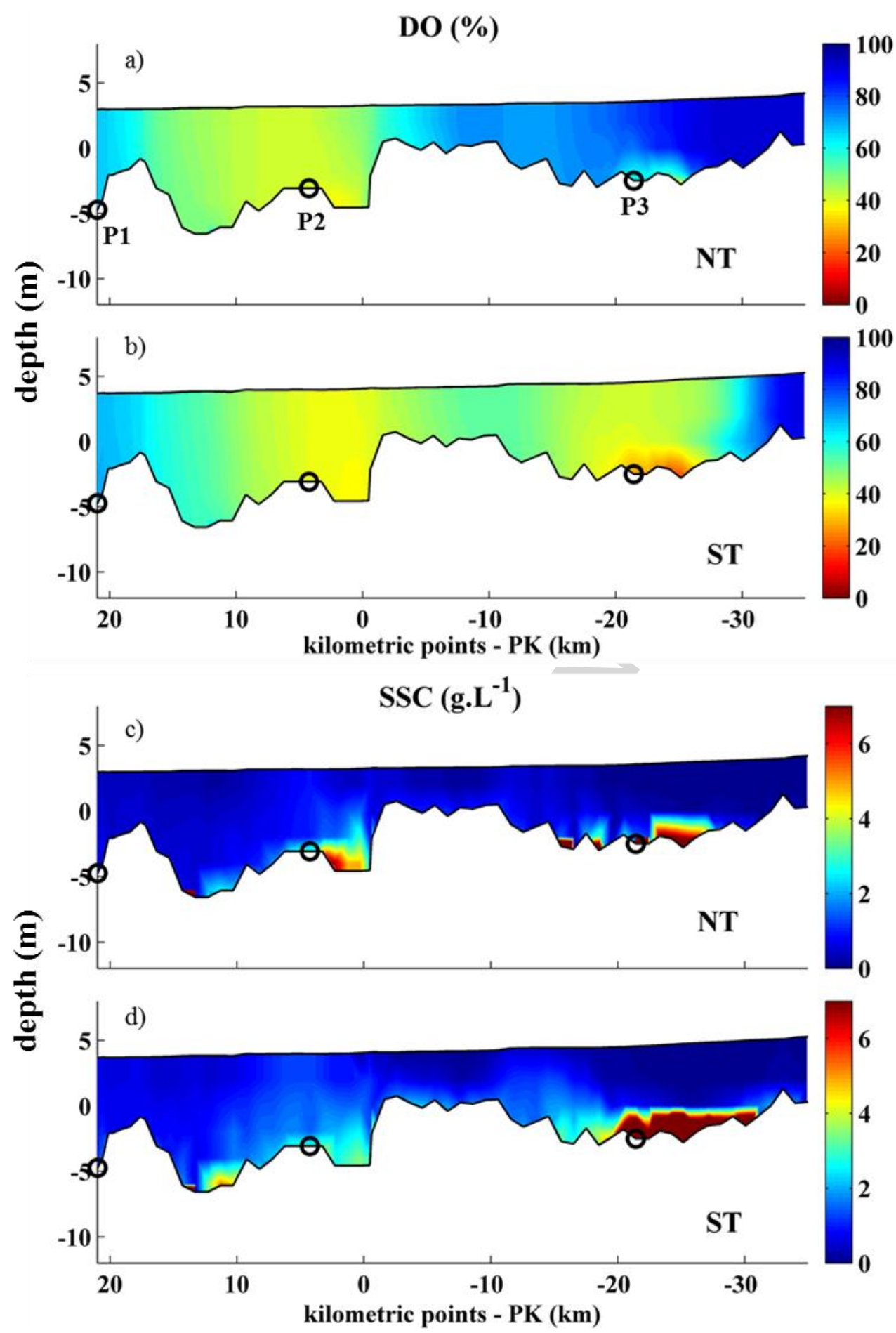
Figure 9
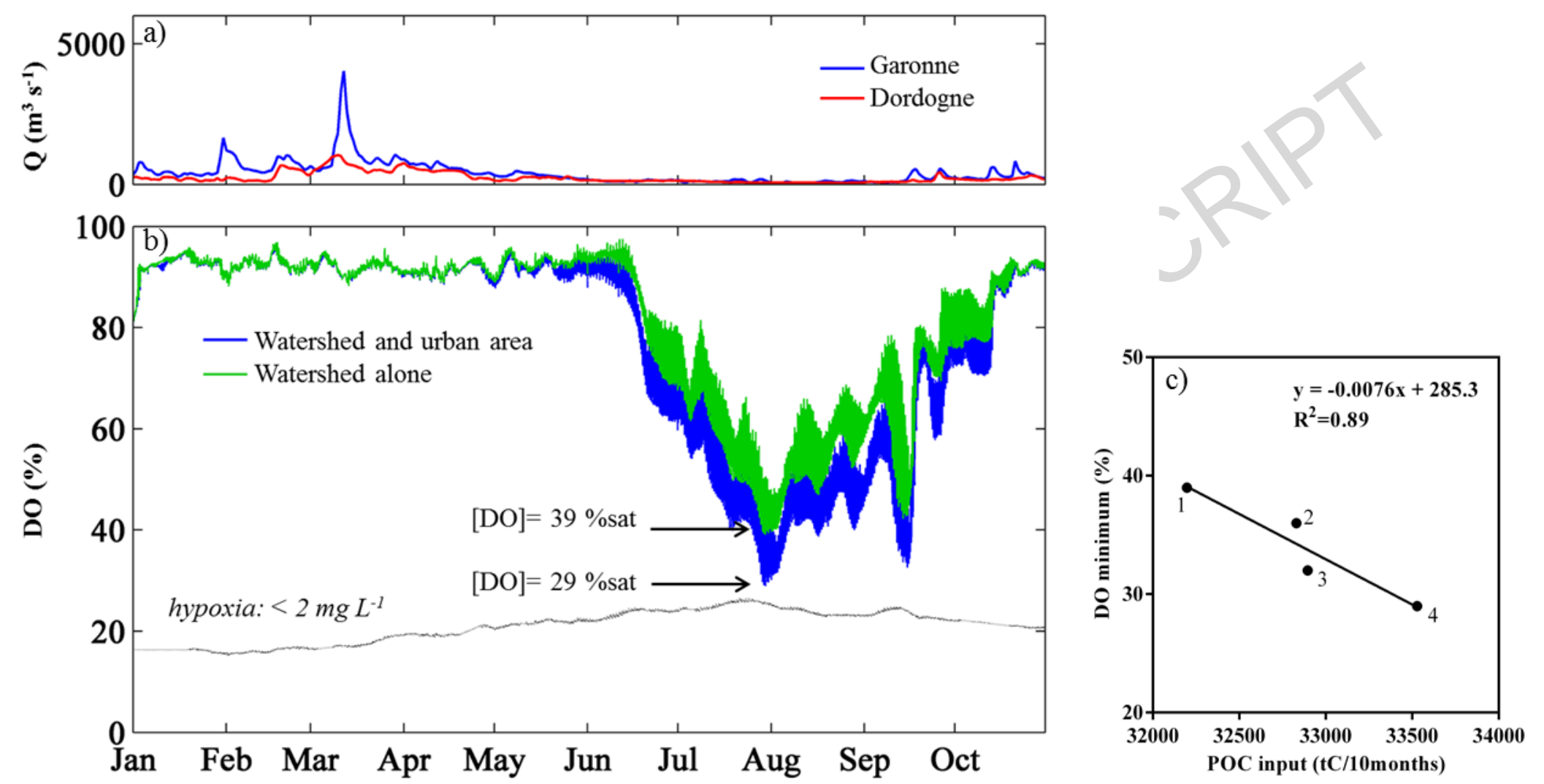


\section{Appendix}

\section{Table A1: Transport model equations and parameters}

\begin{tabular}{|c|c|}
\hline \multicolumn{2}{|c|}{ Settling velocity Ws (in m.s ${ }^{-1}$ ) (Le Hir et al., 2000) } \\
\hline $\begin{array}{l}\text { for } C \leq C_{w_{\max }}: \\
w_{s}=\max \left(w_{\min } ; \frac{w_{\max }}{2} \min (2 ; C)\right) \\
\text { for } C_{w_{\max }}<C \leq C_{c r}: \\
w_{s}=w_{\max }\left(\max \left(0.05 ; \frac{1-\lambda_{1} C^{\lambda_{2}}}{1-\lambda_{1} c_{w_{\max }}^{\lambda_{2}}}\right)^{4.65}\right. \\
\text { for } C>C_{c r}: w_{s}=\gamma_{1} C^{\delta_{1}}\end{array}$ & $\begin{array}{l}\mathrm{C} \text { is the suspended sediment concentration (in kg. } \mathrm{m}^{-3} \text { ) } \\
\mathrm{C}_{\mathrm{wmax}} \text { is the concentration of the maximum settling velocity (end of flocculation), set to } 20 \mathrm{~g} . \mathrm{l}^{-1} \\
\mathrm{C}_{\mathrm{cr}} \text { is the critical concentration for the beginning of hindered settling (set to } 60 \mathrm{~g} . \mathrm{l}^{-1} \text { ) } \\
\mathrm{w}_{\min } \text { and } \mathrm{w}_{\max } \text { are the minimum and maximum settling velocity for a class of particles } \\
\lambda_{1}, \lambda_{2}, \gamma_{1} \text { and } \delta_{1} \text { are empirical constants } \\
\lambda_{1}=0.085 \quad \lambda_{2}=0.5 \\
\text { for the class of heavy particles: } \\
\mathrm{w}_{\min }=0.0005 \mathrm{~m} . \mathrm{s}^{-1} \quad \mathrm{w}_{\max }=0.002 \mathrm{~m} . \mathrm{s}^{-1} \quad \gamma_{1}=120 \quad \delta_{1}=-3.36 \\
\text { for class of light particles: } \\
\mathrm{w}_{\min }=0.0001 \mathrm{~m} . \mathrm{s}^{-1} \quad \mathrm{w}_{\max }=0.001 \mathrm{~m} \cdot \mathrm{s}^{-1} \quad \gamma_{1}=16 \quad \delta_{1}=-3.04\end{array}$ \\
\hline \multicolumn{2}{|l|}{ Effect of decreasing salinity } \\
\hline $\begin{array}{l}\text { if } S \geq S_{\text {lim }}: w_{S}=\max \left(w_{s_{\min }} ; w_{S}\right) \text { (4) } \\
\text { if } S<S_{\text {lim }}: w_{S}=\max \left(w_{s_{\min }} ; \frac{S . w_{S}}{S_{\text {lim }}}\right)\end{array}$ & $\begin{array}{l}\mathrm{S} \text { is the salinity } \\
\mathrm{S}_{\mathrm{lim}} \text { is the salinity limit to start decrease of } w_{S}(\text { set to } \mathrm{S}=5) \\
w_{\text {slim }} \text { is the minimum settling velocity }\end{array}$ \\
\hline \multicolumn{2}{|c|}{ Erosion flux E (in kg.m $\left.{ }^{-2} \cdot \mathrm{s}^{-1}\right)$ (Partheniades, 1965) } \\
\hline$E=E_{o}\left(\frac{\tau_{b}}{\tau_{c e}}-1\right)$ & $\begin{array}{l}\tau_{\mathrm{b}}: \text { bottom shear stress }\left(\mathrm{N} \cdot \mathrm{m}^{-2}\right), \mathrm{E}_{\mathrm{o}}: \text { erosion rate }\left(\mathrm{kg} \cdot \mathrm{m}^{-2} \cdot \mathrm{s}^{-1}\right) \\
\tau_{\mathrm{ce}}: \text { critical shear stress for erosion }\left(\mathrm{N} . \mathrm{m}^{-2}\right) \text {, depends on the the nature of the bed material and of its } \\
\text { consolidation state } \\
\tau_{c e}=x_{1} \cdot C_{\text {sed }} x_{2} \text {, where } \mathrm{C}_{\mathrm{sed}} \text { is the bed sediment concentration, } \mathrm{x}_{1} \text { and } \mathrm{x}_{2} \text { empirical constats } \mathrm{x}_{1}=0.0015 \text { and } \mathrm{x}_{2}=0.1\end{array}$ \\
\hline \multicolumn{2}{|c|}{ Deposition flux D (in kg.m $\left.{ }^{-2} \cdot \mathrm{s}^{-1}\right)($ Krone, 1962$)$} \\
\hline$D=w_{s} C\left(1-\frac{\tau_{b}}{\tau_{c d}}\right)$ & $\begin{array}{l}\tau_{c d}: \text { critical shear stress for deposition }\left(\mathrm{N} \cdot \mathrm{m}^{-2}\right) \\
\mathrm{D}=0 \text { if } \tau_{\mathrm{b}} \geq \tau_{\mathrm{cd}}\end{array}$ \\
\hline
\end{tabular}




\begin{tabular}{|c|c|}
\hline $\begin{array}{l}\text { Eddy viscosity and diffusivity } \\
v_{z}=v_{z 0}+l_{m}^{2} \sqrt{\left(\partial_{x} u\right)^{2}+\left(\partial_{y} v\right)^{2}} \cdot\left(1+\alpha_{1} R i\right)^{\beta_{1}} \\
k_{z}=k_{z 0}+l_{m}^{2} \sqrt{\left(\partial_{x} u\right)^{2}+\left(\partial_{y} v\right)^{2}} \cdot\left(1+\alpha_{2} R i\right)^{\beta_{2}} \\
\text { Mixing length } \\
l_{m}=\left(\kappa \cdot \min \left(z_{f}, h-z_{f}, 0.2 h\right)\right)(10) \\
\text { Richardson number } \\
R i=-\frac{g}{\rho} \cdot \frac{\partial \rho / \partial z}{(\partial u / \partial z)^{2}+(\partial v / \partial z)^{2}} \text { (11) }\end{array}$ & $\begin{array}{l}v_{z} \text { is the vertical eddy viscosity }\left(\mathrm{m}^{2} \cdot \mathrm{s}^{-1}\right), v_{z 0} \text { is a minimum mixing coefficient of } 10^{-5} \mathrm{~m}^{2} \cdot \mathrm{s}^{-1} \\
k_{z} \text { is the vertical eddy diffusivity }\left(\mathrm{m}^{2} \cdot \mathrm{s}^{-1}\right), k_{z 0} \text { is the minimum diffusivity } \\
\mathrm{u} \text { and } \mathrm{v} \text { are the velocity components } \\
\mathrm{l}_{\mathrm{m}} \text { is the mixing length } \\
\mathrm{Ri} \text { : Richardson number } \\
\alpha_{1}, \alpha_{2}, \beta_{1}, \beta_{2} \text { are empirical constants }\left(\alpha_{1}=, \alpha_{2}, \beta_{1}, \beta_{2}\right. \\
\kappa \text { is the von Karman constant }(\kappa=0.4) \\
z_{f} \text { is the distance from the bottom, } \mathrm{h} \text { is the water level, } \mathrm{z} \text { is the vertical coordinate } \\
\rho \text { is the water density, } \mathrm{g} \text { is the gravitational acceleration }\end{array}$ \\
\hline
\end{tabular}


Table A2: Non-conservative terms $\left(\beta_{C}\right)$ for each biogeochemical variable

\begin{tabular}{|c|c|c|c|}
\hline Symbols & State variables & Processes & Formulation \\
\hline $\left.\boldsymbol{\beta}_{[P O C}\right]_{S o}$ & POC from SO & Mineralization & $\beta_{[P O C]_{S O}}=-k_{P}^{S O} \cdot f(T) \cdot \frac{[D O]}{[D O]+K_{D O}} \cdot[P O C]_{S O} \cdot(12)$ \\
\hline$\left.\beta_{[P O C}\right]_{W W T P}$ & $\begin{array}{l}\text { POC from } \\
\text { WWTP }\end{array}$ & mineralization & $\beta_{[P O C]_{W W T P}}=-k_{P}^{W W T P} \cdot f(T) \cdot \frac{[D O]}{[D O]+K_{D O}} \cdot[P O C]_{W W T P}$ \\
\hline $\left.\boldsymbol{\beta}_{[P O C}\right]_{l i t t e r}$ & $\begin{array}{l}\text { POC from } \\
\text { litter }\end{array}$ & mineralization & $\beta_{[P O C]_{l i t t e r}}=-k_{P}^{\text {litter }} \cdot f(T) \cdot \frac{[D O]}{[D O]+K_{D O}} \cdot[P O C]_{\text {litter }}$ \\
\hline $\left.\boldsymbol{\beta}_{[P O C}\right]_{\text {detritus }}$ & $\begin{array}{l}\text { POC from } \\
\text { detritus }\end{array}$ & $\begin{array}{l}\text { mineralization, } \\
\text { mortality }\end{array}$ & $\beta_{[P O C]_{\text {detritus }}}=-k_{P}^{\text {detritus }} \cdot f(T) \cdot \frac{[D O]}{[D O]+K_{D O}} \cdot[P O C]_{\text {detritus }}+k_{m} \cdot[P O C]_{\text {phyto }}$ \\
\hline $\left.\boldsymbol{\beta}_{[P O C}\right]_{p h y t o}$ & $\begin{array}{l}\text { POC from } \\
\text { phytoplankton }\end{array}$ & $\begin{array}{l}\text { growth, } \\
\text { respiration, } \\
\text { mortality }\end{array}$ & $G_{\text {pmax }} \cdot \theta^{T-T_{\text {ref }}} \cdot f(I) \cdot f(N) \cdot[P O C]_{\text {phyto }}-k_{R} \cdot f(T) \cdot \frac{[D O]}{[D O]+K_{D O}} \cdot[P O C]_{\text {phyto }}-k_{m} \cdot[P O C]_{\text {phyto }}$ (16) \\
\hline $\left.\boldsymbol{\beta}_{[D O C}\right]_{s o}$ & DOC from $\mathrm{SO}$ & mineralization & $\beta_{[D O C]_{C S O}}=-k_{D}^{S O} \cdot f(T) \cdot \frac{[D O]}{[D O]+K_{D O}} \cdot[D O C]_{S O}$ \\
\hline $\left.\boldsymbol{\beta}_{[D O C}\right]_{W W T P}$ & $\begin{array}{l}\text { DOC from } \\
\text { WWTP }\end{array}$ & Mineralization & $\beta_{[D O C]_{W W T P}}=-k_{D}^{W W T P} \cdot f(T) \cdot \frac{[D O]}{[D O]+K_{D O}} \cdot[D O C]_{W W T P}$ \\
\hline $\left.\boldsymbol{\beta}_{[D O C}\right]_{\text {fluvial }}$ & $\begin{array}{l}\text { DOC from } \\
\text { upstream }\end{array}$ & Mineralization & $\beta_{[D O C]_{\text {fluvial }}}=-k_{D}^{\text {fluvial }} \cdot f(T) \cdot \frac{[D O]}{[D O]+K_{D O}} \cdot[D O C]_{\text {fluvial }}$ \\
\hline
\end{tabular}




\begin{tabular}{|c|c|c|c|}
\hline Symbols & State variables & Processes & Formulation \\
\hline $\left.\boldsymbol{\beta}_{\left[\mathrm{NH}_{4}\right.}{ }^{+}\right]$ & Ammonium & $\begin{array}{l}\text { mineralization, } \\
\text { uptake, } \\
\text { nitrification }\end{array}$ & $\begin{array}{l}\beta_{\left[\mathrm{NH}_{4}{ }^{+}\right]}=\left(\frac{N}{C}\right) \cdot\left(\sum_{i=3} k_{P \cdot}^{i} \cdot[P O C]_{i}+\sum_{j=3} k_{D}^{j} \cdot[P O C]_{j}\right) \cdot f(T) \cdot \frac{[D O]}{[D O]+K_{D O}}+\left(\frac{N}{C}\right)_{P h} \cdot\left[\left(k_{P}^{\text {detritus }} \cdot[P O C]_{\text {detritus }}+\right.\right. \\
\left.\left.k_{R} \cdot[P O C]_{p h y t o}\right) \cdot f(T) \cdot \frac{[D O]}{[D O]+K_{D O}}-\alpha_{N} \cdot G_{p m a x} \cdot \theta^{T-T_{r e f}} \cdot f(I) \cdot f(N) \cdot[P O C]_{\text {phyto }}\right]- \\
k_{n i t} \cdot f(T) \cdot \frac{\left[N_{4}{ }^{+}\right]}{\left[\mathrm{NH}_{4}{ }^{+}\right]+K_{N_{4}^{+}}} \cdot \frac{[D O]}{[D O]+K_{D O n i t}} \cdot\left[N_{4}{ }^{+}\right](20) \\
\text { i= SO, WWTP, litter and j=SO,WWTP, fluvial }\end{array}$ \\
\hline $\left.\boldsymbol{\beta}_{\left[\mathrm{NO}_{3}\right.}{ }^{-}\right]$ & Nitrate & $\begin{array}{l}\text { nitrification, } \\
\text { uptake }\end{array}$ & $\beta_{\left[\mathrm{NO}_{3}{ }^{-}\right]}=k_{n i t} \cdot f(T) \cdot \frac{\left[\mathrm{NH}_{4}^{+}\right]}{\left[\mathrm{NH}_{4}{ }^{+}\right]+K_{N H_{4}^{+}}} \cdot \frac{[D O]}{[D O]+K_{\text {DOnit }}} \cdot\left[\mathrm{NH}_{4}{ }^{+}\right]-\left(\frac{N}{\mathrm{C}}\right)_{P h}\left(1-\alpha_{N}\right) \cdot G_{\text {pmax }} \cdot \theta^{T-T_{\text {ref }}} \cdot f(I) \cdot f(N) \cdot[P O C]_{\text {phyto }}$ (21) \\
\hline $\left.\boldsymbol{\beta}_{[D O}\right]$ & $\begin{array}{l}\text { Dissolved } \\
\text { oxygen }\end{array}$ & $\begin{array}{l}\text { aeration, } \\
\text { growth, } \\
\text { mineralization, } \\
\text { respiration, } \\
\text { nitrification }\end{array}$ & 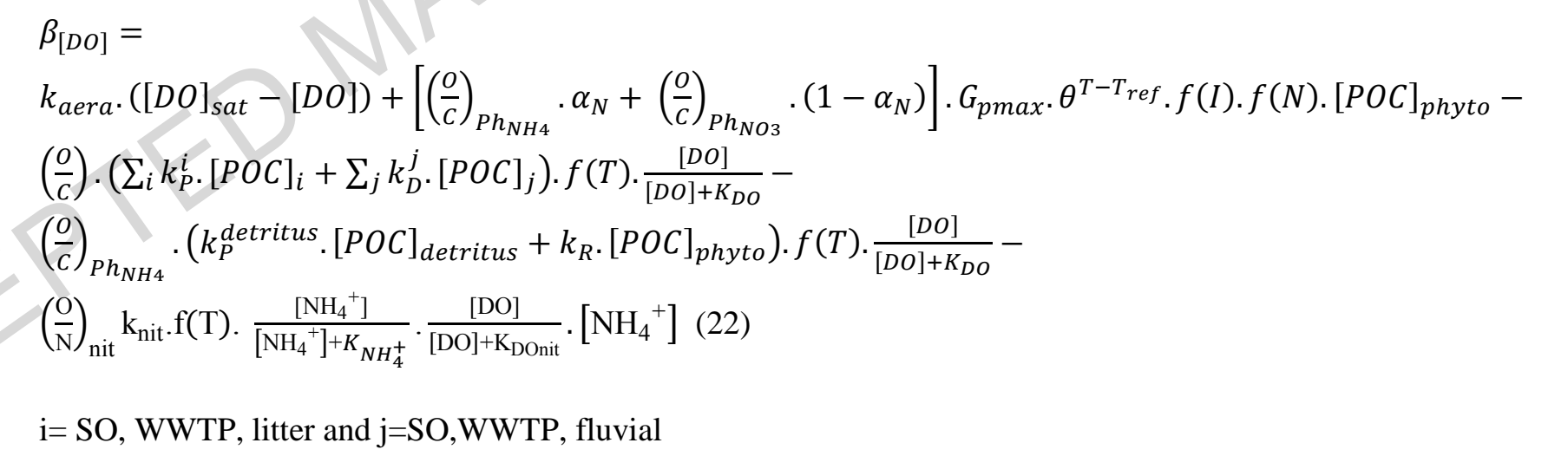 \\
\hline
\end{tabular}


Table A3: Derived model variables (M: measured, B: bibliography)

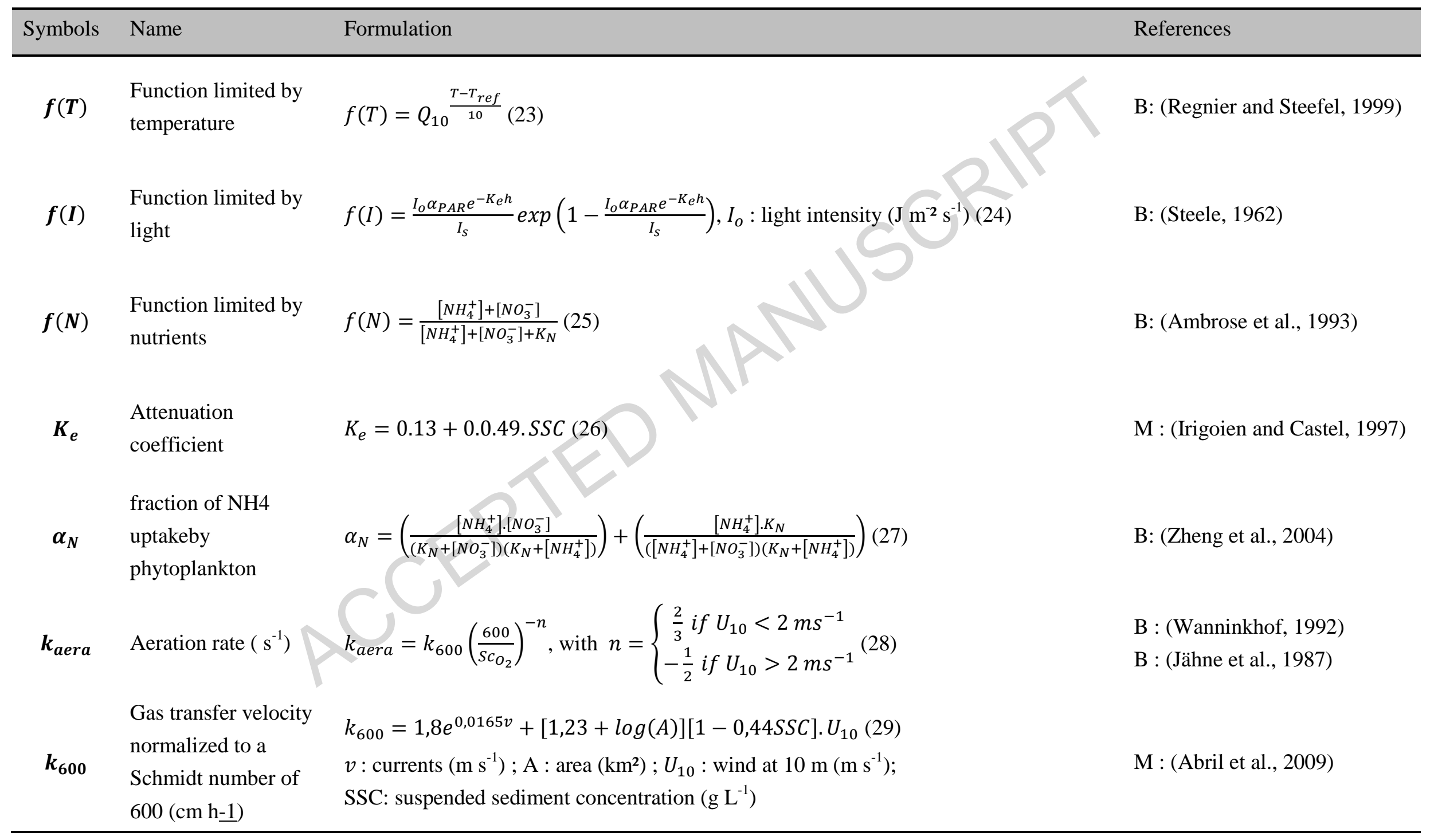




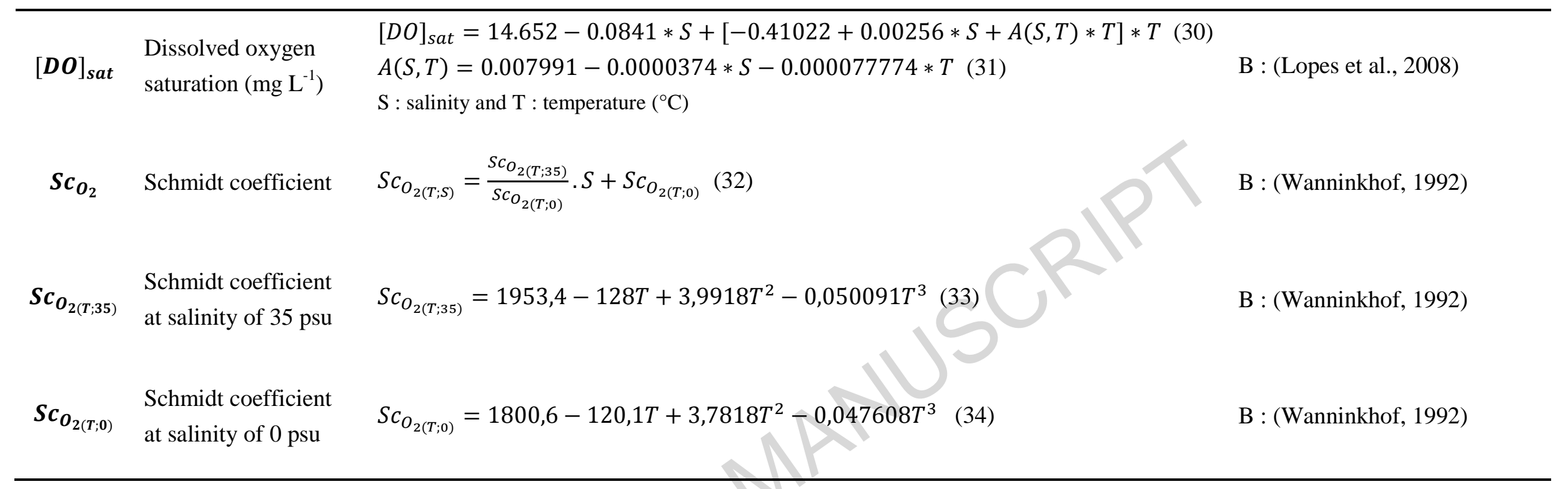


Table A4: Parameters values included in the state variable equations. (M: measured on study area, B: bibliography)

\begin{tabular}{|c|c|c|c|c|}
\hline Symbol & Mineralization & Unit & Value & References \\
\hline$k_{P}^{S O}$ & kinetics mineralization of POC from sewage overflow & $d^{-1}$ & 0.4 & M: (Lanoux, 2013) \\
\hline$k_{P}^{W W T P}$ & kinetics mineralization of POC from wastewater treatment plant & $d^{-1}$ & 0.3 & M: (Lanoux, 2013) \\
\hline $\boldsymbol{k}_{P}^{\text {litter }}$ & kinetics mineralization of POC from litter & $d^{-1}$ & & M: (Lemaire, 2002) \\
\hline$k_{P}^{\text {detritus }}$ & Kinetics mineralization of POC from detritus & & 0.01 & M: (Lemaire, 2002) \\
\hline$k_{D}^{S o}$ & kinetics mineralization of DOC from sewage overflow & & 0.2 & M: (Lanoux, 2013) \\
\hline$k_{D}^{W W T P}$ & kinetics mineralization of DOC from wastewater treat & $d^{-1}$ & 0.08 & M: (Lanoux, 2013) \\
\hline$k_{D}^{\text {fluvial }}$ & kinetics mineralization of DOC from upstream & $d^{-1}$ & 0.005 & M: (Lemaire, 2002) \\
\hline $\boldsymbol{k}_{\mathrm{R}}$ & Rate respiration of phytoplankton & $d^{-1}$ & 0.03 & M: (Lemaire, 2002) \\
\hline$K_{D O}$ & Half-saturation constant of DO for mineralization & $\mu \mathrm{mol} \mathrm{L}{ }^{-1}$ & 15 & B: (Regnier and Steefel, 1999) \\
\hline$Q_{10}$ & Temperature coefficient for mineralization & / & 2 & B: (Regnier and Steefel, 1999) \\
\hline$T_{\text {ref }}$ & Temperature of referenc & ${ }^{\circ} \mathrm{C}$ & 20 & / \\
\hline$C / N$ & Ratio of carbon to nitrogen & I & 10 & l \\
\hline$O / C$ & Ratio of oxygen to carbon & / & 1 & / \\
\hline Symbol & Photosynthesis & & & \\
\hline$G_{p m a x}$ & Maximal growth rate of phytoplankton & $d^{-1}$ & 0.25 & B: (Thouvenin et al., 1994) \\
\hline$K_{N}$ & Half-saturation constant for $\mathrm{N}$ & $\mu \mathrm{mol} \mathrm{L}-1$ & 0.714 & B: (Xue et al., 2014) \\
\hline$I_{s}$ & Light intensity of saturation & $\mathrm{J} \mathrm{m}^{-2} \mathrm{~s}^{-1}$ & 145 & B: (Di Toro et al., 1977) \\
\hline
\end{tabular}




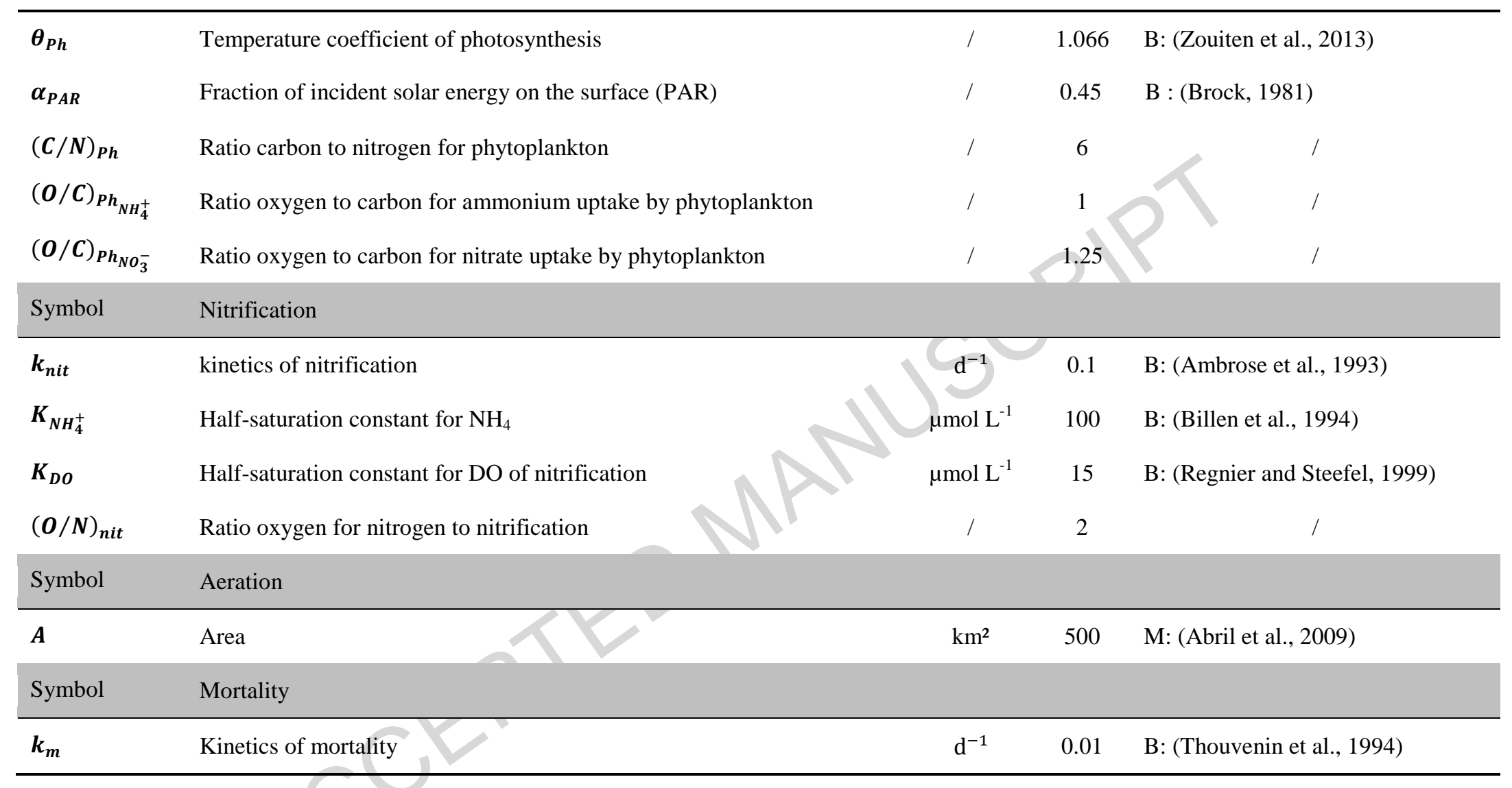

